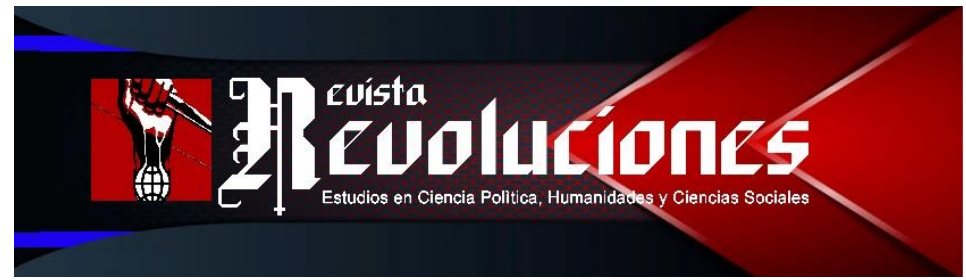

ARTÍCULO ORIGINAL

\title{
"EL PUEBLO ME RECLAMA Y DEBO ESTAR CON ÉL”. LA REVOLUCIÓN DE PEDRO VILCAPAZA EN AZÁNGARO, $1780-1782$
}

\author{
"The people demand me and must be with them". The revolution of \\ Pedro Vilcapaza in Azángaro, 1780 - 1782 \\ Franz Lenin Condori-Alvarez ${ }^{1}$ \\ UNIVERSIDAD NACIONAL DEL ALTIPLANO \\ PERÚ \\ franz.lenin.20@gmail.com \\ https://orcid.org/o000-0003-1747-1709
}

DOI: https://doi.org/10.35622/j.rr.2021.04.003

Recibido: 03-VII-2020 / Aceptado: 13-VII-2021 / Actualizado: 06-VIII-2021

\begin{abstract}
Resumen
El presente trabajo de investigación tiene el propósito de analizar el desarrollo histórico de la sublevación del caudillo Pedro Vilcapaza Alarcón en la provincia de Azángaro: 1780 - 1782, quien fuera personaje revolucionario más importante del altiplano puneño que se caracterizó por combatir en sangrientas batallas frente a la opresión de los españoles. De este modo, mediante la revisión documental y del análisis del contenido se puede determinar que, la extraordinaria época de su muerte, de su gloria y el anhelo de emancipación en las regiones del sur, lo hicieron uno de los cadillos más representativos de la tierra indígena. Así, Azángaro resultó ser sede de la rebelión de uno de los sucesos históricos más importantes de la época colonial, región que brindó a su pueblo masas decididas a luchar por la libertad y de ofrecer caudillos dignos de la inmortalidad.
\end{abstract}

Palabras Clave: Batallas, colonialismo, revolución, Azángaro, Pedro Vilcapaza.

\section{Abstract}

The present research work has the purpose of analyzing the historical development of the uprising of the caudillo Pedro Vilcapaza Alarcón in the province of Azángaro: 1780 - 1782,

\footnotetext{
${ }^{1}$ Docente Pre-Universitario. Bachiller en Educación Secundaria con mención en Ciencias Sociales, Licenciado en Ciencias de la Educación, Maestrando en Investigación y Docencia Universitaria en la Unidad de Postgrado de la Facultad de Ciencias Sociales. Estudios concluidos en maestría en Educación con Mención en Didáctica de las Ciencias Sociales de la Escuela de Posgrado de la Universidad Nacional del Altiplano de Puno [UNAP].
}

ISSN: 2710-0499 ISSN-L: 2710-0480

Esta obra está bajo una licencia internacional Creative Commons Atribución 4.0. 
who was the most important revolutionary character of the Puno highlands who was characterized by fighting in bloody battles against the oppression of the Spanish. In this way, through documentary review and content analysis, it can be determined that the extraordinary time of his death, of his glory and the desire for emancipation in the southern regions, made him one of the most representative cadillos on earth. indigenous. Thus, Azángaro turned out to be the seat of the rebellion of one of the most important historical events of the colonial era, a region that provided its people with masses determined to fight for freedom and to offer leaders worthy of immortality.

Keyword: Battles, colonialism, revolution, Azángaro, Pedro Vilcapaza.

\section{INTRODUCCIÓN}

En siglo XVIII brotan vigorosos levantamientos indígenas, los más grandes de nuestra historia, el de Juan Santos Antahualpa en 1974, el de Túpac Amaru II en cuzco y el del precursor Pedro Vilcapaza en Azángaro de 1780. De esta manera, la epoca de la sublevación en el altiplano puneño, especialmente en Azángaro estuvo envuelto por poderosos caudillos y de indígenas que habían dado muestra de honor y sacrificio del poderío de los Choquihuancas (Ortiz, 2013).

Según Luna (1982), la personalidad de un pueblo se mide por su pasado histórico o, en otros términos, por su grandeza pretérita. Se mide también por su contribución a las grandes causas de la libertad y la justicia, y paralelamente por sus hombres representativos. Mas lejos de los lejos, "Aswan Karu”, Azángaro es el roquedal inhiesto donde nace aquel Puma Indomable que sacude la conciencia de su pueblo y lega un ejemplo de altivez, virilidad y patriotismo en la épica gesta libertaria de 1781 a 1782.

En el año 2016, Machaca mencionaba que en el proceso de la independencia peruana la población puñera jugo un papel preponderante. En los años de la revolución tupacamarista la hoy región Puno hizo uno de los principales escenarios; es más, en 1781 y por ocho meses, en el Perú resulto libre, teniendo por epicentro al pueblo de Azángaro en esta revolución el puneño que más destaco fue Pedro Vilcapaza. Uno de los acontecimientos históricos de trascendencia del proceso de la independencia peruana ocurrió en tierras puneñas, son las batallas de Condorcuyo, Qanqari. Kimsa Sullk'a que se ha constituido en la principal contienda de la revolución de 1781-1782 y simboliza la gallarda lucha del ejército patriota que quedará como un acontecimiento histórico en nuestras mentes.

De acuerdo a Tamayo (1984), menciona que la historia de un país debe ir de la mano con los tiempos, sin dejar de estudiarse y transmitir a las nuevas generaciones los hechos y acontecimientos, es decir la verdadera historia local. En realidad, desde hace poco tiempo se escucha hablar de la historia regional en el Perú, a pesar de que su trayectoria es muy antigua, y hoy como historiadores o como estudiosos, nos toca la responsabilidad de dar cuenta de su existencia y de su importancia a las nuevas generaciones.

Revista Revoluciones -27- Vol. 3, No 4 (2021), pp. 26-55

Esta obra está bajo una licencia internacional Creative Commons Atribución 4.0. 
Así, el insatisfecho patriota hizo que la rebelión llegue en el siglo XVIII, para sobrevivir sus opresiones inhumanas. De ello no extraña que en ese siglo, Azángaro haya sido un océano embravecido de masas indias que rumian en silencio sus cóleras impotentes, sus dolores y angustias, bajo la férula brutal de los explotadores hispanos y mestizos. Como islotes sobre el mar turbulentos, caciques de rancio abolengo incaico, leales vasallos y servidores del rey, explotan sus respectivos rebaños. Dueños de extensas tierras, amo y señores absolutos del capital humano que vive en ellas cifraban todo su orgullo en sostener sendos títulos nobiliarios, distinciones honorificas, como escudos de armas y hasta marqueseados, que les otorgaban el virrey en recompensa a su fidelidad y adhesión a los monarcas católicos de España (Luna, 1982).

Las huestes derrotadas y perseguidas de Túpac Amaru II, buscaron refugio en las frígidas zonas del altiplano puneño, sabedores que en ellas se habían encendido la llama de la rebelión. Ahí se constituiría un nuevo ejército compuesto fundamentalmente por los aguerridos kollas y que tendría por misión concluir la obra iniciada por el caudillo que en ese momento era prisionero de los españoles en el Cuzco. El nuevo jefe eligió la ciudad de Azángaro como el centro y la capital de todas las provincias alzadas y que se hallaban bajo el dominio de las tropas. La elección no era, casual.

En esas aperturas, el presente estudio tiene el propósito de analizar el desarrollo histórico de la sublevación del caudillo Pedro Vilcapaza Alarcón en la provincia de Azángaro: 1780 - 1782, quien fuera personaje revolucionario más importante del altiplano puneño que se caracterizó por combatir en sangrientas batallas frente a la opresión de los españoles. De este modo, mediante la revisión documental y del análisis del contenido se puede determinar que, la extraordinaria época de su muerte, de su gloria y el anhelo de emancipación en las regiones del sur, lo hicieron uno de los cadillos más representativos de la tierra indígena. Así, Azángaro resultó ser sede de la rebelión de uno de los sucesos históricos más importantes de la época colonial, región que brindó a su pueblo masas decididas a luchar por la libertad y de ofrecer caudillos dignos de la inmortalidad.

\section{METODOLOGÍA}

Desde el paradigma cualitativo se busca analizar todos los sucesos históricos de la manera más objetiva y exacta posible, para lo cual se recolecta, evalúa, verifica y sintetiza evidencias de tipo documental. La investigación corresponde al tipo histórico/enfoque cualitativo (Huanca-Arohuanca, 2019; 2020a; 2020b; 2020c; 2020d; 2021; Huanca-Arohuanca \& Núñez, 2020; Huanca-Arohuanca \& Geldrech, 2020; Huanca-Arohuanca et al., 2020; Huanca-Arohuanca, Canaza-Choque, et al., 2020; Huanca-Arohuanca \& Pilco, 2021), que "es multimetódica, interpretativo y naturalista hacia su objetivo de estudio" (Palomino, 2010, p. 250). La misma que tiene como propósito buscar, reconstruir el pasado de manera que permita verificar y sintetizar evidencias para obtener conclusiones válidas.

Revista Revoluciones -28- Vol. 3, No 4 (2021), pp. 26-55 
De igual modo, el diseño de investigación histórica o de reconstrucción narrativa tiene como proposito establecer sucesos, ocurrencias o en un ambito y tiempo deterninado (Charaja (2018, p. 134). En ese sentido se desarrollo primero la revisión de fuentes bibliográficas y textos que estuvieran relacionados con temas referentes a la Sublevación Pedro Vilcapaza, particularmente, libros, revistas, periódicos, memorias, las mismas que se encontraron en bibliotecas especializadas y en fuentes digitales. En segundo lugar, se seleccionó la información de acuerdo al interés del investigador y la naturaleza del tema de investigación (Canaza-Choque, Supo, Ruelas, \& Yabar, 2020; Canaza-Choque, 2019; 2020a; 2020b; 2020c; 2020d; 2021a; 2021b; 2021c; Canaza-Choque, Cornejo-Valdivia, Condori-Pilco, YabarMiranda, 2021).

\section{RESULTADOS}

\section{La vida de Pedro Vilcapaza Alarcón}

Desde la perspectiva antropológica y sociológica, diversos escritores e historiadores dedicaron su investigación, con la finalidad de reconstruir la vida y lucha del gran prócer y mártir azangarino Pedro Vilcapaza Alaracón de raíz noble y mestizo, hombre que secundó la rebelión de José Gabriel Condorcanqui Noguera con el apelativo Túpac Amaru II, en 1780.

El ilustre escritor azangarino Lizandro Luna, de la misma forma Pompeo Aragón magnificado de las cualidades personales de Pedro Vilcapaza, escribió con bastante elocuencia con referente al nacimiento y el noble apellido textualmente dice: "A veinte kilómetros de Azángaro y al Noroeste esta la parcialidad de Moro Orco. Sobre la columna vertebral de los andes, vio la primera luz Pedro Vilcapaza" (Luna, 1952, p. 36 ).

No hay duda que el General Vilcapaza ha nacido en junio de 1740, en el lugar denominado Tapatapa, sitio enclavado entre las haciendas de Arco punco y Oqcra. En la casa de propiedad de sus padres, situado en una pequeña eminencia de cadena de cerros que ascienden hacia Vizcachani y el ayllu Umabamba de la parcialidad de Mororqo, comprendió entonces del extenso ayllu Qollana-Jurinsaya, que se extendía desde las puertas de la ciudad Azángaro, hasta los límites con Carabaya, sobre el rio crucero el padre fue propietario de Tapatapa. La madre habría sido una indígena de apellido desconocido o que no guarda la tradición, habría sido oriunda de Muñani, pueblo importante, con el que, por la proximidad los de Mororqo tenían más contacto que con Azángaro mismo. (Aragón, 1977). Los vilcapazas. Descendía de los Wilca cuyos ancestros fueron probablemente los primeros habitantes de aquel ayllu. Por línea materna, tenía sangre y espíritu aimara. Procedía de la aguerrida y fiera raza Lupaca chucuito y el alto Perú. El nombre de Vilcapaza es sinónimo de caudillo rebelde, veamos su etimología. Vilcapaza es el nombre españolizado de Wilaca o Wilca Apuwasa. Wilca está formado de las raíces aimaras Wila, es sangre y Laca, boca. Significaría boca sangrienta o fauces con sangre, algo de fiera de un animal de presa. Apaza está conformado por los vocablos apu, es el jefe y wasa, es detrás o espalda. Vilcapaza significaría pues el que tiene presencia o estatura de caudillo. Señala este nombre seguramente, una posición social o una 
presencia guerrera. (Luna, 1952) El apellido de nuestro héroe fue y sigue siendo Vilcapaza y no Vilca Apaza como muchos escriben. Es un apellido quechua.

No obstante, en lo que abarca el aspecto estrictamente biográfico según la versión del Dr. Francisco chukiwanca Ayul, tomada por su hijo Reynaldo chukiwanca. Durand (1973) nos dice que: "Pedro Vilcapaza Alarcón nació en su estancia de Moro-Orcco, el 29 de junio de 1740” (p.19). En la Revista Nº1, Biografía: Pedro Vilcapaza, 8 de Abril del año 2009, se ratifica y aclara algunos datos importantes, como sigue: En el sitio llamado Qochapampa Tapatapa nació Pedro Vilcapaza, sus padres fueron Cleto Vilcapasa Obaya (aunque otros sostienen como clemente), descendiente directo de Roque Zapana, su ancestro principal fue Antonio Vilcapaza Amaru, fue indio noble previsión virreinal del conde de Lemos, tronco principal de los Willcas. Su madre Juana Alarcón Apaza, una mestiza descendiente directo del capitán español Martin Alarcón.

Con el correr de los primeros estudios se precisa que Pedro Vilcapaza fue el segundo de cinco hermanos. Salas (1997) afirma que Vilcapaza: "Fue el segundo de cinco hermanos, Toribio, Pedro, Gerónimo, Francisco, Antonia” (p.17).

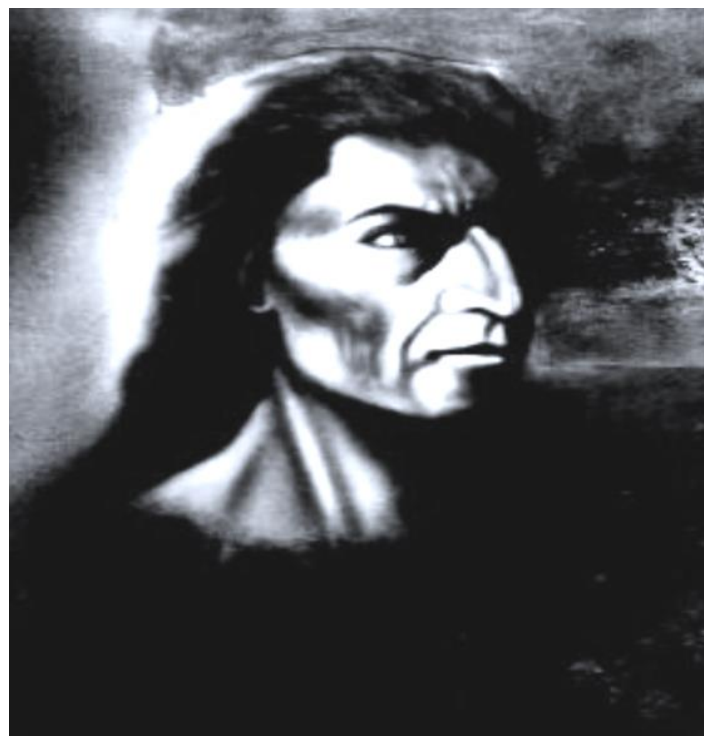

Figura 1. Pedro Vilcapaza

Fuente: Este cuadro es una escenificación a Pedro Vilcapaza fue uno de los que encabezo los más grandes movimientos campesinos e indígenas en Azángaro - Puno. Óleo sobre lienzo UNAP (Condori, 2015).

\section{Educación de Pedro Vilcapaza Alarcón}

Sobre la educación de Pedro Vilcapaza, el biógrafo Mario Millares, nos presenta un resaltante dato, precisando que su madre, Juana Alarcón consiguió que se admitiera al pequeño Pedro Vilcapaza en el Real Colegio de Caciques de San Bernardo en el Cuzco (Millares, 2004) Sobre este indicio conjeturamos que la señora Juana Alarcón fue una mestiza, descendiente del primer encomendero de Azángaro, el capitán español Martin Alarcón, Juana Alarcón utilizo 
influencias de posición social, para la educación de su hijo en un centro de elite española. Por consiguiente, Pedro Vilcapaza Alarcón fue un mestizo, educado en el colegio de caciques del Cuzco, preparado para asumir el cacicazgo en el territorio de su repartimiento.

Otro dato nos refiere Sivirichi, al decir que Pedro Vilcapaza Alarcón. "Posteriormente paso al colegio San Francisco de Borja del Cuzco" (Canahuiri, 1994, p. 94). Lo que indica que Vilcapaza había recibido una buena educación en el cuzco.

En el año de 1850 cuyo subprefecto de la provincia de Azángaro del año ya mencionado, el $\mathrm{Sr}$ Modesto Basadre después de 60 años de rebelión de Vilcapaza menciona que, según la tradición local, Pedro Vilcapaza había recibido una buena educación en el cuzco. Razón por la cual Vilcapaza había conocido bien la historia, pues había recibido una buena educación en el colegio del Cuzco (Romero, 2003). Después de los primeros estudios, ingresa como soldado del ejército real, donde permanece durante tres años consecutivos obteniendo el grado de sargento Siller de Caballería. De regreso a su tierra natal en setiembre de 1771 se dedica al comercio de mercaderías, como arriero y trajinante. Seguramente de esos hombres que llevaba lana del Collao a los obrajes de Quispicanchis, que en aquella oportunidad eran los principales centros textiles de la región sur andina. El comercio que se extiende entre el cuzco y Potosí, movilizaba recuas de mulas con cargamento de coca y de metales (Luna, 1982).

Después de sus estudios en el Cuzco, ingresa como soldado del ejército Real, donde permanece durante tres años consecutivos, obteniendo el grado de Sargenti de Siller de caballería. (Paredes, 2014). El caudillo Pedro Vilcapaza, como militar del ejército Real, reconocido con el grado de "sargento sillero" de caballería; al asumir el caudillaje de la Revolución Vilcapacina, actúa como cabeza y guía, al mando de la gente de guerra: los patriotas, allí es donde fue reconocido por el populacho como "General Vilcapaza", un merecido y cabal reconocimiento por los indios, que perdura en el tiempo, como un genuino sentir de los azangarinos y puneños (Machaca, 2016, p. 28).

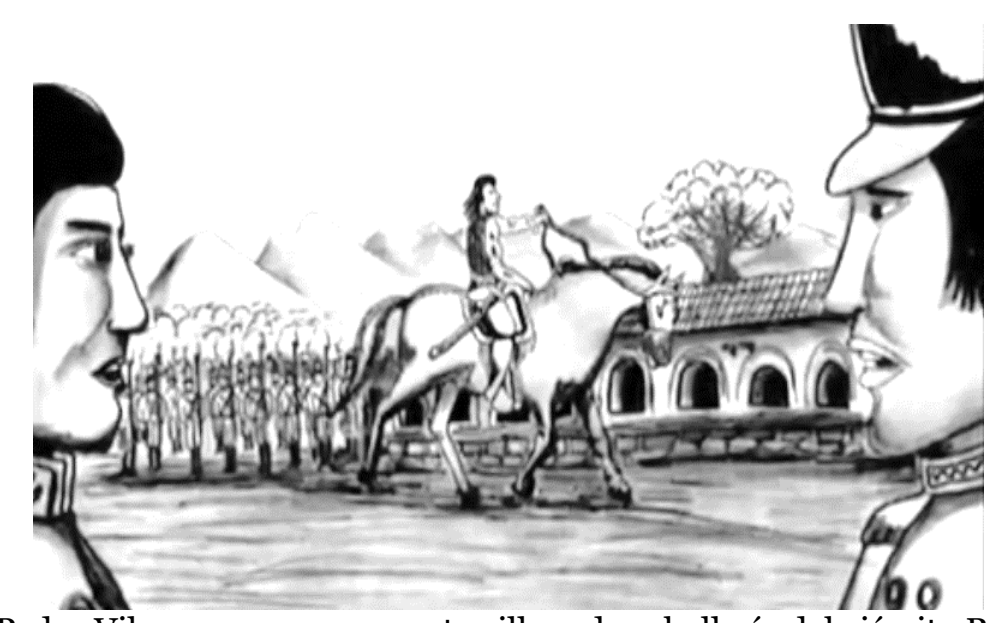

Figura 2. Pedro Vilcapaza como sargento sillero de caballería del ejército Real del Cuzco.

Fuente: Livisi (2017).

Según la tradición local Pedro Vilcapaza a su corta de edad demuestra un conocimiento superior a los indios de Azángaro, donde se indica que Vilcapaza conocía bien la historia de su pueblo y sabia la lengua española. Ramos y Mamani (2009) recuperaron de un documento antiquísimo. Donde muestra, la firma legible del héroe: 
Don Pedro Vilcapaza, principal del ayllu Moro-Orco, ladino en la lengua castellana, a quien le mande a leer de la relación (...) dijo que estaba bien enterado del castellano (...) y lo firmo conmigo y testigos, a falta de escribano-firmado Antonio del Villar Mariño. Juan Pacheco. Pedro Vilcapaza y dos más con firmas ilegibles. (p.27)

En este proceso el Caudillo Pedro Vilcapaza, como testigo ofrecido por los indígenas denunciantes. Con toda la contundencia y serenidad manifiesta llamarse como tal, de 22 años de edad; indio principal de Azángaro, con conocimiento del castellano por lo que no necesitaba interprete, alfabeto por saber escribir; reconocer ser pariente por afinidad con el denunciado Diego Choquehuanca.

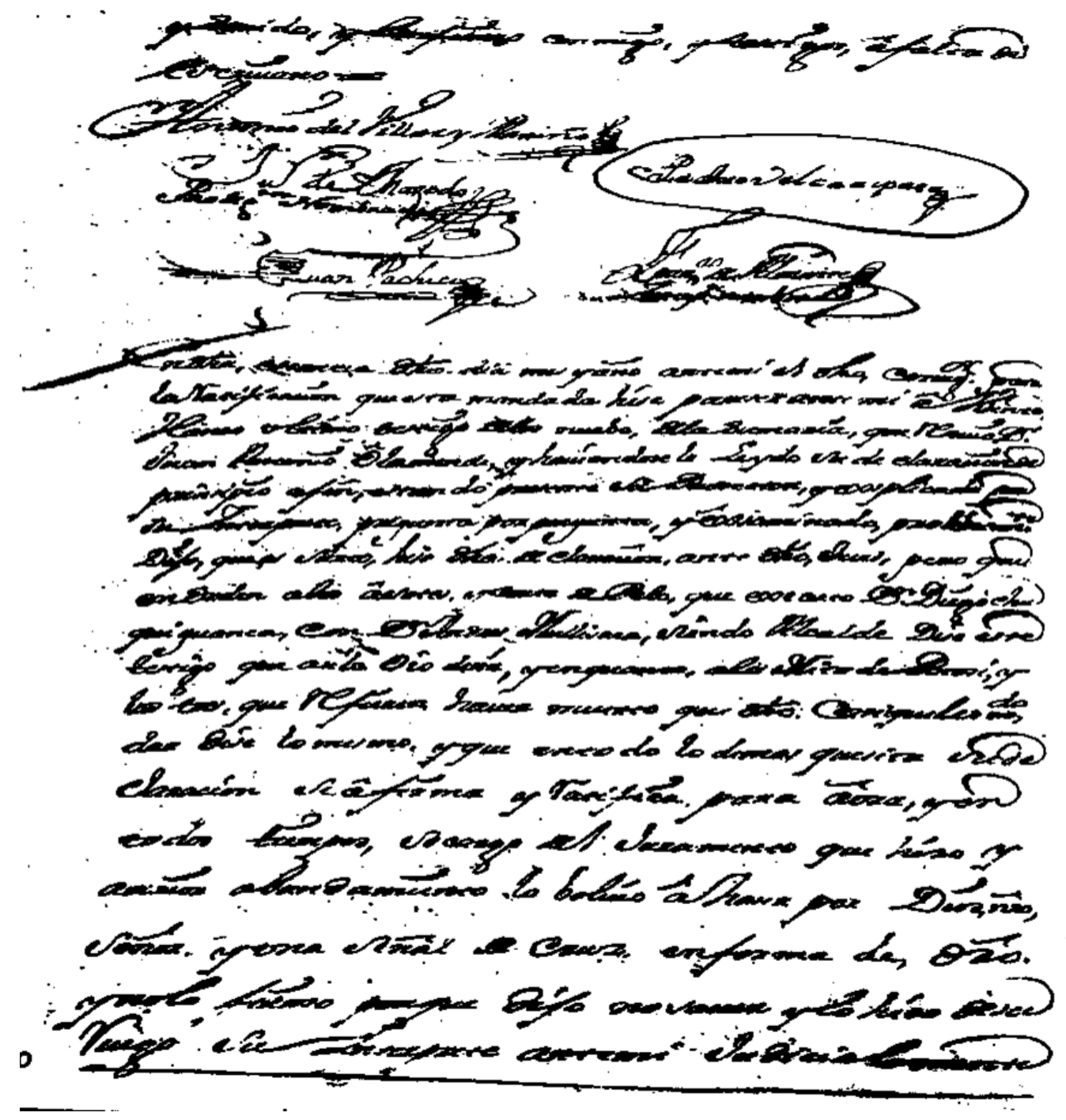

Figura 3. Firma de Pedro Vilcapaza.

Fuente: Archivo histórico de Sucre (Ramos, 1982, p. 400).

Lo cual indica que Vilcapaza a la edad de 22 años, ya supo leer, escribir y tenía la facilidad de hablar la lengua castellana esto expresa que años más antes a 1762 ya tuvo que haber realizado 
sus estudios para así luego ingresar a las filas del ejército realista, con relación a este tema el escritor Fortunato Turpo sustenta que. Turpo (1971) sostiene que: infundido con el frio certero de las punas en la mente de cualquier niño, inteligente y audaz, en su temprana edad ingresa al colegio Real de San Bernardo del Cuzco y posteriormente se enfile al ejército español (p. 29).

\section{Vida conyugal de Pedro Vilcapaza}

Pedro Vilcapaza se enfila al ejército español. De retorno a su tierra natal el 25 de agosto 1771, contrae matrimonio, con doña Manuela Copacondori Choquehuanca. La información recogida por Modesto Basadre es la que más se aproxima a la posición social y económica de Manuela Copacondori y el matrimonio con Pedro Vilcapaza, lo que indica que contrajo matrimonio con una acaudalada mujer llamada Manuela Copacondori Chuquihuanca, sobrina de Diego Choquehuanca quien sirvió de padrino.

El comentario insistente de que su mujer lo abandono como consecuencia de la rebelión es muy probable, debido a que ya en su ancianidad hace donación de la finca de Nequeneque a doña María del Rosario Choquehuanca, hermana de José Domingo Choquehuanca, llamándole así "sobrina preferida", lo que evidencia que manuela de Vilcapaza se mantenía fiel a los Chuquihuanca, Pedro Vilcapaza se casa con la dama azangarina Manuela Copacondori Chuiquihuanca, una acaudala azangarina, quien lo abandona antes de iniciar la revolución al valeroso Puma Indomable, apodo con el cual era conocido el General (Espezúa, 2006). Sobre su descendencia de Vilcapaza. Se ignora si dejo o no descendencia directa.

El general Pedro Vilcapaza, fue bautizado en Muñani, y se casó con una joven y bella indígena también de Muñani, llamada Rosario con quien tuvieron a Leonarda Vilcapaza, única hija de Rosario, en toda la campaña guerrera, habría seguido, a su esposo, en todas sus virtudes. Rosario y Leonarda (Aragón, 1977). Después de la acción de Kimsa-Sullk’a en el que el General fue aprehendido, habrían sido llevadas; por sus parientes, a las alturas de Puna Ayllu, en Cuyucuyo (Sandia), para librarles de la sevicia de los Pukakuncas. No se supo más de ellas.

\section{Actividad pública de Pedro Vilcapaza: La arriería}

Una cualidad particular y resaltante como persona publica Pedro Vilcapaza Según. Vega (1981) sostiene que Vilcapaza fue: "arriero azangarino, militó desde un inicio en las filas tupacaristas” (p. 459). Pedro Vilcapaza tuvo que ser arriero. De otro modo jamás habría podido conectarse con las corrientes conspirativas de su época. En sus trajines debió conocer de hombres de igual oficio, entre ellos a los Túpac Amaru, quien por otra parte eran viajeros frecuentes por el Collao, hasta Potosí. Quizá llego hasta Arequipa, puesto que ciñéndose a la estadística de Azángaro elaborado por J.D. Choquehuanca, hacia 1830, podríamos inducir que traía a las punas coca y ají de las altas selvas carabainas de San Gabán y del Alto Inambari y aguardientes y chancacas de los valles arequipeños; de Azángaro llevaría ocas, quinuas y frazadas, lanas, charquis y chuño, entre otros productos. Seguramente más de una vez llevo lana del Collao a los obrajes cusqueños de Quispicanchis que entre los mayores centros textiles de las comarcas sur andinas.

Revista Revoluciones -33- Vol. 3, No 4 (2021), pp. 26-55 
Durante su vida Pedro Vilcapaza fue comerciante y arriero, recorrió Potosí, La Plata, Chuisaca, Huamanga y las ferias famosas de esa época de Vilquechico. Rosaspata, Pucará, Lampa. En sus recuas de acémilas transportaba mercadería de región a región entre Cuzco, Puno, Arequipa, Alto Perú. Es probable que haya llegado a Lima donde se relacionó con gente de toda índole y en especial con aquellos que fomentaba la Revolución.

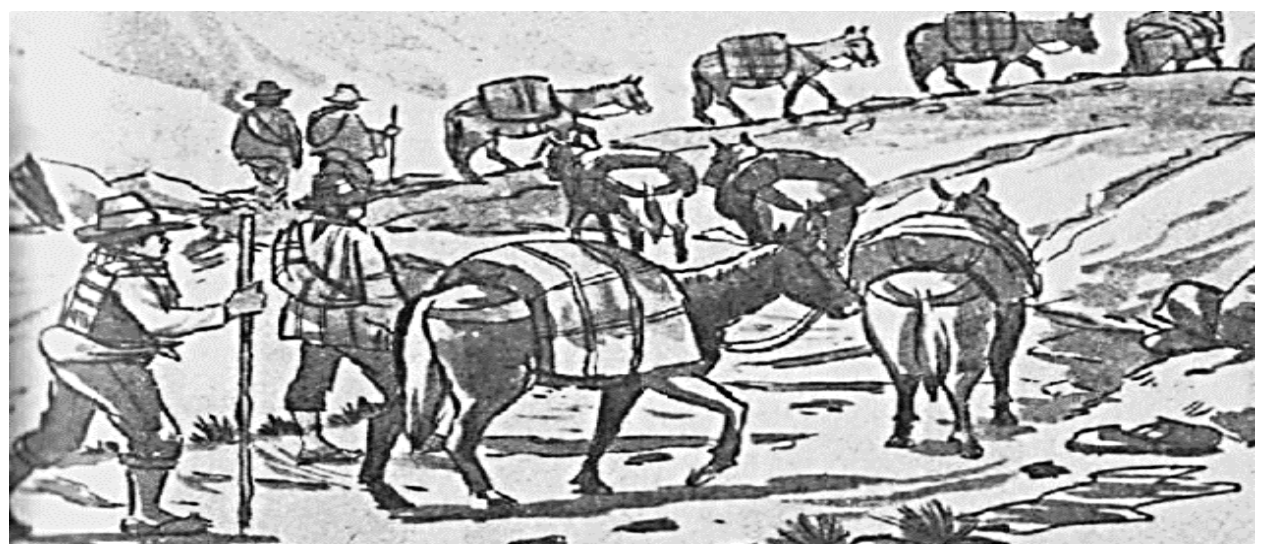

Figura 4. Arrieros llevando cargamentos de la sierra.

Fuente: Los Andes (2018).

Vilcapaza se ha dedicado en su juventud al comercio o negocio de mercadería, que recorrió a los cuatro puntos cardinales del vasto territorio de la patria ofendida, ultraja y oprimida por los chapetones españoles y estos viajes de experiencias dio lugar a tomar conciencia y trasportar ideas y planes revolucionarios a la masa indígena y estos mismos viajes sirvió a Vilcapaza para analizar, planear y conjuncionar ideas revolucionarias con José Gabriel Túpac Amaru y Julián Túpac Catari. Ramos (2014) manifiesta, como una consecuencia, que: "Pedro Vilcapaza, tras haberse dedicado al comercio entre Cuzco y Potosí, se convenció de la rebelión emancipadora" (p. 91). Por otro lado, se considera a los arrieros como un grupo social de avanzada en la sociedad andina: No olvidemos que la mayor parte de los dirigentes de la sublevación andina fueron arrieros, y esto no puede ser una coincidencia. No solo fue arriero José Gabriel Túpac Amaru, fue arriero Diego Cristóbal Túpac Amaru, Túpac Catarí Julián Apaza, el famosos líder Pedro Vilcapaza líder azangarino quien contaban con más de un centenar de acémilas, otro tanto de llamas, que arreaban junto con ovejas que servían para la alimentación en los largos viajes.

\section{Batallas}

En 1780 estalla en el Perú la primera gran rebelión indígena contra el dominio colonial hispano. La encabeza un descendiente de los antiguos reyes del Cuzco Túpac Amaru II o José Gabriel Condorcanqui Noguera. El 4 de Noviembre de 1780 Pedro Vilcapaza estuvo presente en el estallamiento de la revolución Tupacamarista, en la captura del Corregidor de Tinta, Coronel Antonio de Arriaga, donde Vilcapaza participa activamente en los planes de la revolución, su capacidad organizativa, su enorme ascendencia, en las masas campesinas, su valentía y coraje hacen de él, el auténtico caudillo; estuvo presente en el combate donde se 
apresa y sentencian al corregidor de tinta Antonio de Arriaga camino a Yanaoca. Al mismo tiempo se capturo también al secretario del corregidor y algunos esclavos negros que le hacían la escolta, al estallar la rebelión de 1780, Vilcapaza asume la jefatura del alzamiento en su provincia de Azángaro formando un ejército de guerrilleras con la colaboración de algunos de sus familiares como Manuel Vilcapaza y otros indios principales que tiene destacada participación. Su actuación posterior hasta su apresamiento y descuartizamiento.

El general Vilcapaza aposto sus tropas en la fortaleza de Condorcuyo. Condorcuyo o "KunturK'uyo" ubicada al pie del cerro Condorcuyo que hoy pertenece al distrito de San José. Está a 18 kilómetros al norte de Azángaro. Aragón (1977) señala que:

El cerro o montaña de Condorcuyo que hacia nombre a la localidad de arriba indicada y en donde se desarrolla la acción de la guerrera, es parte central de una cadena de más de 25 kilómetros de extensión y que recorre de sureste y noreste. Los sitios más importantes y más escarpados de la montaña son: "LLaulli, Kondorqaqa y surpo" constituye las fortalezas porque estaban amurallados había servido de fortaleza a indios asangarinos que se sublevaron cansados de pagar tributos y soportar esclavizaciones de encomenderos abusivos (p. 18).

Pero los patriotas en sus corazones flameaban la esperanza de triunfar y lograr valientemente ganar todas las batallas que podrían presentarse hasta el último momento de la libertad.

\section{Primera batalla Condorcuyo}

En la primera batalla de Condorcuyo se demostró un verdadero heroísmo de parte del ejército revolucionario contra Diego Choquehuanca. Canahuire y Mamani (2016) afirman que la primera batalla se llevó: El 30 de marzo de 1781. Entre Asillo y Azángaro. El cacique Diego Choquehuanca defendiendo a la realeza se enfrentó al ejército rebelde de Vilcapaza, en la primera batalla de Condorcuyo; en esta contienda el ejército realista fue derrotado y Choquehuanca en fin, de cosas decide retirarse de Azángaro. (p. 125)

Diego Choquehuanca, cacique de Azángaro, cumpliendo un papel similar a los demás caciques, pues con un ejército de 12 mil indios de Anta y Chincheros, enfrento al precursor Pedro Vilcapaza, en la batalla de Condorcuyo; pero lamentablemente, fue derrotado por el ejército revolucionario, luego de su fracaso se retiró definitivamente de su tierra.

La lucha más campal más sangrienta y de resistencia en la historia de la humanidad, se inicia el 30 de marzo de 1781 en el legendario Pukara de Condorcuyo, la vociferante legión de indio de Anta y chincheros dirigido por el general Pumacahua comienza el ataque de guerra por el lado sur, intercambiando voces de insulto con los defensores, pero que la escena sangrienta favoreció al ejército revolucionario hasta en tres oportunidades de ataque, donde fueron fácilmente aniquilados, declarándoles en momento de vergüenza y desconcierto, teniendo el triste resultado de una carnicería y una fuga masiva de los indios de Anta y Chincheros y del traidor Choquehuanca. 
Diego Choquehuanca, después de la primera batalla en el enigmático pucara de la montaña de Condorcuyo, decido refugiarse en Arequipa durante la rebelión de Tupac Amaru y Pedro Vilcapaza, tal como indica. El diario de los Andes (2014) Donde indica que: "Se refugió Diego Choquehuanca en Arequipa durante la rebelión de Túpac Amaru II"

Después de la derrota de los Choquehuancas por parte del ejército revolucionario dirigido por Pedro Vilcapaza, derrotado Diego Choquehuanca en la primera batalla de Condorcuyo, toman la decisión de dividirse en dos grupos y parten en dos direcciones para proteger sus vidas, en Arequipa y Sorata, donde se puede leer el párrafo donde. Ramos (2009) indica:

El destino para Choquehuanca fue demasiado adverso. En primer lugar las tropas rebeldes de Azángaro al mando de caudillos como Vilcapaza, Melchor Laura y otros; destruyeron sus haciendas, saquearon sus ganados y todos sus bienes. Por otro lado, también tuvo que dirigirse con sus hijos a un lugar seguro y cuando se encontraban con todos ellos cerca de la frontera con el Alto Perú divido a sus vástagos; de tal manera el Coronel Blas, María y Teresa continuaron hasta Sorata. Sensiblemente el trayecto y en la localidad de Escoma, María cayo al rio muriendo ahogada. En el asalto de Sorata, fue tomado prisionero y ejecutado su hijo el coronel Blas Chukihuanca; mientras que Teresa, caminando a pie varios días busco refugio en el convento de Copacabana. El cacique Diego y sus hijos el sargento mayor José y el Eclesiástico Gregorio, tuvieron mejor suerte porque al dirigirse a la ciudad de Arequipa contaron con la protección del corregidor don Baltasar de Sematnat. Desde allí, desde allá escribía cartas a los virreyes del Perú y Buenos Aires quejándose amargamente; declarando que se encontraba en estado de mendicidad. Desde los comienzos de la gran rebelión hasta la pacificación, reunió numerosas certificaciones, de los inmensos perjuicios que había sufrido durante la rebelión, así como su inquebrantable lealtad al Rey. (p. 107)

Diego Choquehuanca durante su refugio en la ciudad de Arequipa, actuó sabiamente en favor de su familia.

\section{Segunda Batalla de Condorcuyo}

El ejército realista prosiguió su marcha hacia el pueblo de Azángaro desde Orurillo, el 7 de mayo de 1781, donde solo encontró a los ancianos, niños y mujeres; mientras que los jóvenes habían marchado junto con el ejército revolucionario que ellos preferían morir que antes de convertirse en servil del rey de España (Seraylán, 1984, p. 89).

Del 9 al 12 de mayo permanece el ejército realista en el distrito de Asillo. El Mariscal José del Valle, después de dar descanso a sus tropas por el agotamiento y deserción en Sicuani: emprendió la marcha hacia el sur, a fin de pacificar aquellas tierras aledañas (...) llego a la provincia de Azángaro y al pueblo de Asillo donde apreso al cura, José Maruri que había estado en relación con los rebeldes. El cerro de condorcuyo el valiente Caudillo Pedro Vilcapaza organizo una gran resistencia donde lucharon con una gran desesperación entre el ejército realista y el ejército patriota donde sale como vencedores los realistas.

La Batalla de Condorcuyo se ha desarrollado el 13 y el 14 de mayo de 1781, en la fortaleza de Condorcuyo en el primer día se dio una victoria triunfal del ejército patriota y al día siguiente

Revista Revoluciones -36- Vol. 3, No 4 (2021), pp. 26-55

Esta obra está bajo una licencia internacional Creative Commons Atribución 4.o. 
fue la arremetida por toda la fuerza realista, que permitió la dispersión de las fuerzas patriotas hacia el norte de Azángaro a diferentes lugares. Palomino (2011) afirma: "El 13 y 14 de mayo estalla la segunda batalla de Condorcuyo, entre el ejército rebelde del General Pedro Vilcapaza junto a Ambrosio Huamán Tapara, enfrentando al ejército virreinal del Mariscal José del Valle" (p. 84).

A una hora y media de camino a Asillo, en la Pampa Condorcuyo los patriotas ocupan el cerro Condorcuyo coronando las cumbres con banderas, clarienes y con un rumor tan extraordinario de confusas voces todas dirigidas a insultar e enfurecer a los virreinales. Todo el conjunto daba la impresión que 10 mil hombres ocupaba el cerro. Los patriotas estaban a órdenes de Pedro Vilcapaza con gente de Azángaro y Carabaya.

El general Pedro Vilcapaza, por su parte, fuerte en la escarpada montaña reforzó su pukara. Dividió su ejército en tres partes, Una división se presentó en el lado sur, en la eminencia de "Surpo" para defenderse de los enemigos que venían por la cuchillada. Otra, en el escarpado kondorqaqa, el más fuerte, para operar contra los atacantes del lado de Rio "Qari Mayo". Y la tercera división se aposto en las cumbres de "Llaulli", al norte para proteger la retirada hacia Inampu, caso de ser necesario (Aragón, 1977). El ejército sanguinario sedientos de sangre, dirigido por el Marical José del Valle se hace presente en las pampas o al pie de la fortaleza de Condorkuyo y en las orillas del rio Qari Mayo, conformado por 17 mil soldados entre españoles e indios venidos desde Anta y Chincheros, en señal de venganza con una multitudinaria y vociferante legión de españoles e indios.

La vanguardia del teniente coronel Juan Manuel Campos es rechazada con piedras. Del Valle envía los auxiliares de Anta Chincheros para que bocearan a patriotas que mejor era rendirse y que serían perdonados. Los patriotas respondieron con su objetivo era dirigirse a Cuzco a poner en libertad a su Inca. Ante un gran impulso de asalto patriota, del Valle ordena suspender su ataque.

El 14 de mayo, el Mariscal José del Valle decide atacar a los patriotas fortificados en Condorcuyo por diferentes columnas y por las direcciones siguientes:

- Una por la retaguardia del cerro y desbordándolo, con la misión de batir a los demás enemigos que bájense en retirada. Para ello esta columna salió a ocupar sus posiciones dos antes a órdenes de Joaquín Valcárcel.

- Otra columna a órdenes del coronel Avilés que debía subir a atacar el cerro por el cerro frontal y hacia la derecha del campo virreinal.

- La tercera columna a órdenes del comandante Campero para atacar por el sector frontal y hacia la izquierda.

Un destacamento en reserva para actuar en emergencia. La columna de Avilés ataco el sector derecho y logro desalojarlos de esta posición a las fuerzas de Vilcapaza y pasar al lado opuesto reforzando ese sector. La columna de Campero entro en resistencia tenaz debido a que los patriotas se reforzaron con los desalojados del sector derecho. Campero que atacaba el flanco izquierdo con 1500 hombres fue rechazado por tres veces con fuego de fusil y tiros de piedra,

Revista Revoluciones =37- Vol. 3, No 4 (2021), pp. 26-55 
sosteniéndose los patriotas obstinadamente en un paso estrecho. El heroísmo de un soldado patriota que, atravesado con una lanza, se la saco del pecho y siguió con ella a su contrario cinco seis pasos hasta caer muerto, otro a que con un golpe de lanza se le saco un ojo, pero continuo con empeño al que le había herido, que si otro soldado virreinal no acaba con él, hubiese puesto fin a la vida de su agresor.

Mientras se desarrollaba la batalla, los patriotas reciben refuerzos que se ubican en una columna cerca al monte, vistas desde el campo del Valle con los anteojos, se envió de inmediato el destacamento de auxilio a órdenes de José Antonio Vibal, quien logro hacerles replegar. Seraylán (1984) afirma que:

Los patriotas atacados en el cerro Condorcuyo por todos los frentes se defendieron con obstinación desprendiendo galgas y atacando aun las mujeres. Pero la disposición del ataque virreinal y la actuación de los auxiliares (aliados) Anta y Chincheros que al decir del Valle en ese día estuvieron muy bizarros, logro desalojar a los patriotas y obligar la retirada (p.886).

José del Valle se dio con la tremenda sorpresa de encontrase con soldados decididos a morir por la liberta y justica. El heroísmo ofrecido por Vilcapaza, y sus hombres en aquel histórico bastión de Condorcuyo no tenía precedentes en los combates que antes se liberaron. Todos los documentos existentes sobre el particular procedente de fuentes exclusivamente hispanas señalan que en esta batalla los indios estaban muy lejos de ser humildes esclavos y vasallos de otros lugares (Frisancho, 1980). En la columna de Avilés mataron: un capitán, a un soldado de caballería, e hirieron en la cabeza al ayúdate de campo, y a cinco soldados. En la columna de Campero hirieron al gravemente al coronel Allende con una pedrada en el pecho, $y$ al mismo tiempo Campero. Asimismo, fueron heridos, el teniente coronel Pablo Astete y 80 soldados más haciendo un total de 94 heridos y 25 muertos. Según los españoles entre los patriotas hubo 600 muertos. Los virreinales se declararon vencedores en esta batalla

El General del Valle apresa a 67 andinos, muchos heridos. Ordena decapitar a todos. Clavan sus cabezas a la orilla de los caminos. Los ataques incaicos se intensifican, los españoles concentran sus fuerzas en los poblados, abandonando la mayor parte del territorio. Lo ejércitos subidos de Lima toman Azángaro. Matan a cuchillos a todos los indios e indias, cuando salen solamente quedan vivos unos pocos ancianos y niños (Reinaga, 1977, p. 118). 


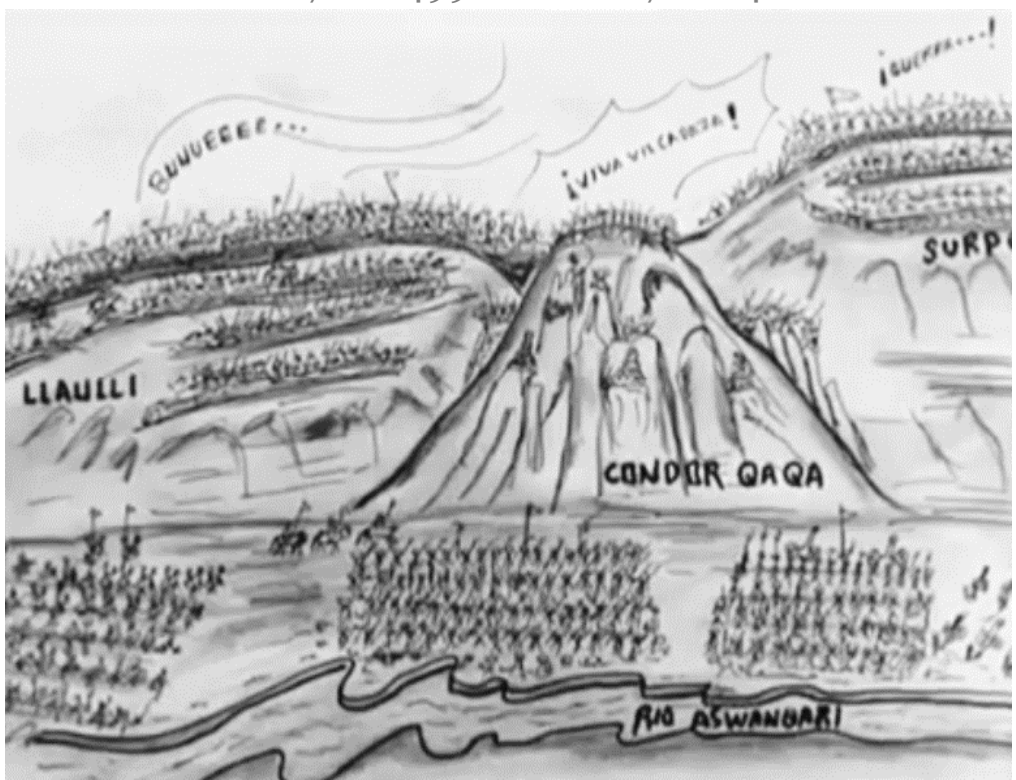

Figura 5. La Batalla realizado entre los ejércitos del Mariscal José del Valle con el ejército del General Pedro Vilcapaza, en la fortaleza de Condorcuyo.

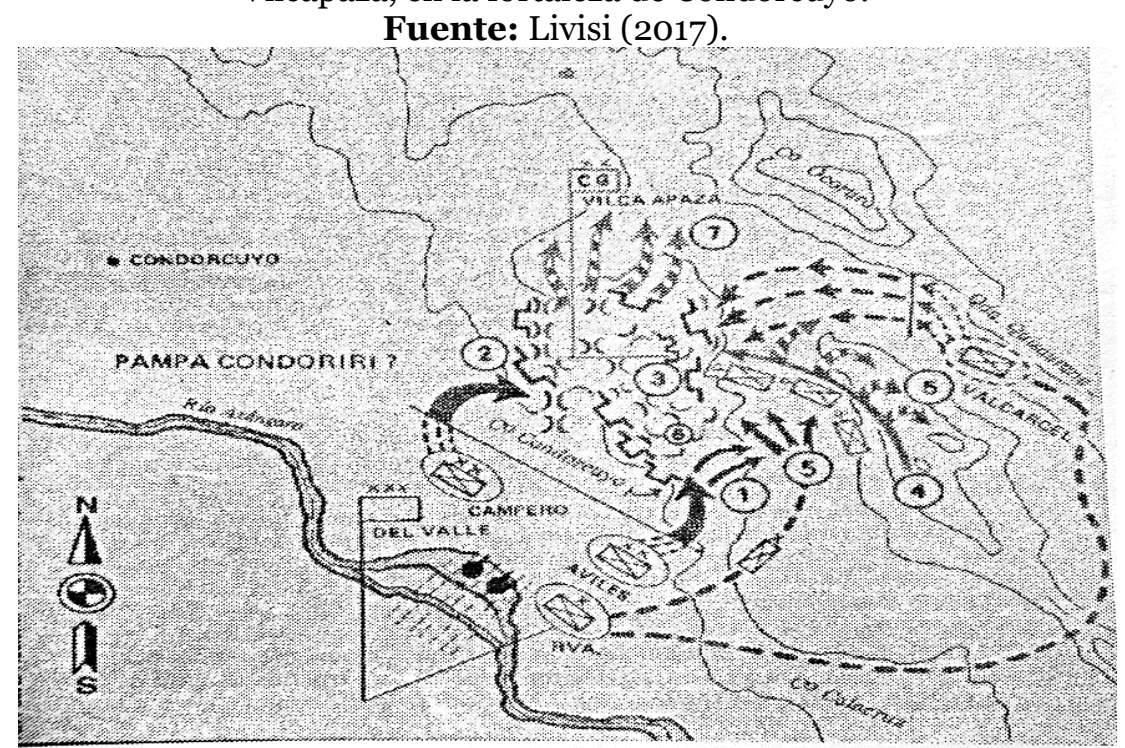

Figura 6. Mapa de la batalla de Condorcuyo. Fuente: Calsín (2005)

\section{Los hechos en Azángaro}

Tras un breve descanso, casi sin cuidar a los heridos, y después apoderarse de mulas, caballos y víveres en Condorcuyo, el jefe realista ordeno continuar su marcha para ingresar a Azángaro, lugar que encontró abandonada por sus moradores, solo encontró un grupo de mujeres, ancianos y niños.

De acuerdo a las indagaciones aquel 15 de mayo del 1781 al entrar en Azángaro del Valle y su ejército después de la batalla Condorcuyo, solo se encontró un Azángaro con unos cuantos ancianos y pocos niños. En tal sentido el pueblo había sido abandonado. Valcárcel (1972) Indica de que "el día 15 de mayo, le avisaron a del valle de que Diego Cristóbal Túpac Amaru, después de su ataque a Puno, estaba acampando a legua y media de distancia” (p. 164). De

Revista Revoluciones -39- Vol. 3, No 4 (2021), pp. 26-55

Esta obra está bajo una licencia internacional Creative Commons Atribución 4.o.

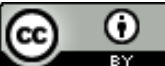


inmediato envió a Avilés con destacamento de 300 fusileros, pero la noticia era falsa. En Azángaro solo había un reducido grupo de ancianos, mujeres y niños.

Según las indagaciones de los historiadores Sevirichi y Seraylán (1979), sostienen que, del Valle tenía como dirección a Putina y decide pasar por Llacchata. El 16 de mayo el mariscal José del Valle se dirige a Putina, con el propósito de alcanzar a Diego Cristóbal Túpac Amaru que ya se dirigía a Carabaya con 100 hombres. Allí se proponía a reclutar se proponía gente para reorganizar su ejército. Para lo cual pernocto en Llacchata, cerro que se encontraba a 12 $\mathrm{km}$ al oriente de Azángaro.

\section{Enfrentamiento Llacchata}

De acuerdo a la indagaciones Mamani y Frisancho, (1968) El día 18 de mayo desde el campo de Llachata, aquí del valle decidió enviar al Coronel Francisco, con tres mil hombres en persecución de Diego Túpac Amaru y para castigar a la provincia de Carabaya, por su decidida contribución en favor de la rebelión. Del Valle con el resto de su ejército tomo rumbo a Puno (p. 74).

El ejército realista que lideraba del Valle es atacado por el ejército patriota de Pedro Vilcapaza, en la comunidad de llacchata, se presume que muy probablemente el ataque fue por la noche. Esa era la estrategia de la tropa de Vilcapaza. En tal sentido estos ataques han podido ser la razón por la cual, del Valle cambie su ruta con dirección a Puno. Donde se menciona que según. Calsín (2005) afirma: "El día 18 una columna virreinal se enfrentaba en Llacchata, ese mismo día las tropas de José del Valle acamparon en Ccalla". Seraylán (1984) del Valle emprende su retirada de Llacchata con dirección a Ccalla (q'alla) el día 18 de mayo en Llacchata envía dos expediciones: La columna del mayor general Don. Francisco Cuellar con 3000 a Carabaya con la misión de ubicar a Diego Cristóbal Thupa Amaru. En este efectivo lleva 2000 auxiliares (aliados) de Anta en sus tropas. La columna de Paruro tenía la misión de regresar a su provincia llevando prisionero al cura de Asilllo. El 18 de mayo del Valle estaciona en el campo de Ccalla.

\section{La batalla de Pukina Qanqhari}

Después de la batalla de Condorcuyo, Vilcapaza aconsejo un repliegue, con el objeto de concentrar. Machaca y Vega (2016), todas las fuerzas rebeldes en un ataque más sobre la ciudad de Puno donde resistía en corregidor Joaquín de Orellana pero su idea de una arremetida así no habría sido aceptada: otros jefes rebeldes, tan anárquicos como valientes, anhelaban como enfrentarse otra vez con el Mariscal del Valle y se arremetieron en el Cerro Puquinacancari.

Cabe indicar que los rebeldes Vilcapacinos se enfrentaron, en el cerro Puquinacancari, en el actual Cerro Campuco, con el ejército del mariscal del Valle y Pumacahua en su trayecto con dirección a Puno. Donde se indica que en este enfrentamiento los patriotas prefirieron el suicidio que rendirse. Donde indica el mismo José del Valle en su informe: 
El 19 de mayo el Mariscal José del Valle sale de Ccalla y se dirige rumbo a Puno, pero, a media hora de camino, desde el centro de una pampa muy dilatada, diviso un monte muy elevado denominado Puquinacancari casi todo de piedra escarpada y sin más subida que la de una senda dificilísima. $\mathrm{Al}$ acercarse al cerro un soldado de la vanguardia da aviso a del valle que en una pequeña peñada situada frente al ejército que se encontraban algunos hombres. Del valle no dio importancia a esta información y continúo su marcha, avanzo un cuarto de legua llegando al ayllu de 80 personas donde se apodera de todos los costales de papa de los pobladores ofreciéndoles pagar, luego llega un aviso de que los patriotas desde el cerro Puquinacancari atacan la retaguardia del ejército virreinal, donde se encontraba la columna de cotabambas, al mando del comandante José María Acuña. Los patriotas cuyo efectivo era de cien hombres y mujeres apedrean con lanzamiento de hondas y descolgando galgas contra la tropa de cotabambas.

Del valle ordeno atacarlos con un pequeño destacamento de 80 fusileros, lo cual no fue suficiente pues de su corto número hicieron una obstinada y bárbara defensa, por lo que Del Valle tiene que retroceder al momento con el regimiento de caballería del Cuzco para rodear el monte por sus faldas para la acción. Al caerme a él, vi, con mucha admiración, el increíble arrojo con que aquella, bárbara gente presente procuraba defender su puesto. Del Valle les ofreció el perdón e indulto, a cambio de su rendición, pero ellos respondieron "con furor que antes querían morir". Virreinales atacan con fuego de fusiles y mantienen cercados a patriotas, por lo que estos decidieron despeñarse cayendo desde alturas de más de 200 metros, antes de rendirse o caer prisioneros. Algunos realizan últimos esfuerzos antes de ser vencidos como patriotas que ganando el tercio del fusil de un soldado virreinal que lo perseguía, forcejeó con intención de despeñarlo y lo hubiera conseguido, por lo escarpado del terreno, pero es socorrido por otro soldado virreinal. Del Valle describe de otra escena lleno de dramatismo: "una mujer prisionera se tendió voluntariamente sobre un cadáver, y viendo que tardaban en matarla, levanto la cabeza y pregunto; ¿Por qué no me matan?”. Todos los patriotas murieron heroicamente. El 19 de mayo luego de la batalla estacionan en corpa desde donde envió carta a Orellana, pidiéndole informes de la situación de puno (Seraylán, 1984, p. 891-894).

A pesar de que los enemigos no pasaban de cien hicieron una obstina y bárbara defensa y viéndose ya sin recursos, algunos se desempeñaron voluntariamente, y entre otros una mujer con un niño en las espaldas. Los pocos que quedaron vivos se ajusticiaron. Una mujer prisionera se tendió voluntariamente sobre un cadáver y viendo que tardaban, levantó la cabeza y dijo: ¿Por qué no me matan? Vega y Mamani (2005) con respecto a Pedro Vilcapaza. "Vilcapaza esa vez, consiguió retirarse a tiempo antes de ser rodeado por el enemigo y paso a organizar núcleos combatientes” (p. 26).

Tras su triunfo sobre las huestes rebeldes en Puquinacancari, el ejército del Mariscal José de Valle continuo su progresión sobre la ciudad de Puno (...) fue una marcha relativamente lenta, por las privaciones y las fuertes heladas del mes de mayo que son comunes en nuestra zona, que afectaban especialmente a las tropas de negros de Lima y el Callao, desafectos a las 
regiones altiplánicas; con todo, tomaron Calapuja, Juliaca y Buenas Vista cercanos a la ciudad de Puno.

Pedro Vilcapaza y su ejército revaloraron un valor combativo y una capacidad de lucha fuera de lo común, donde Vilcapaza demuestra actos heroicos, los heroísmos del caudillo son acontecimientos extraordinarios que no debemos de olvidar.

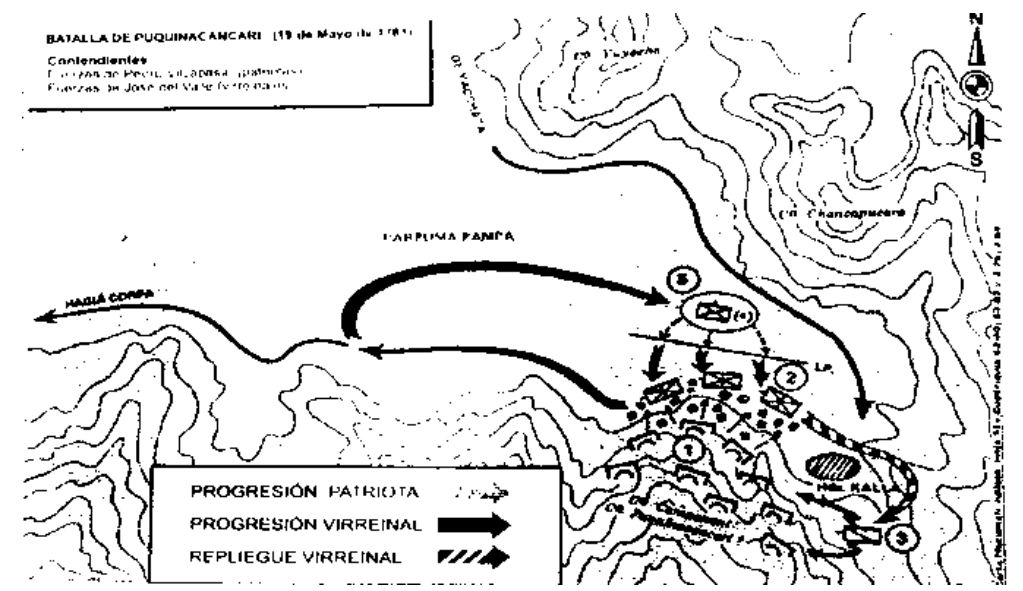

Figura 7. El enfrentamiento entre los realista y los patriotas, mapa de la batalla de Puquinacancari

Fuente: Calsín (2005)

\section{El fraccionamiento de los revolucionarios tupacamaristas y vilcapacinos}

El 1 de octubre de 1781, es cuando José de Valle envía oficialmente desde la ciudad del Cuzco la ley del Indulto a Diego Cristóbal Túpac Amaru, juntamente con una carta, en la que se compromete como militar de alto rango de hacer cumplir la administra, solicitando el cese de fuego, levantamiento y desparramamientos de sangre, hace una referencia a manera de amenaza diciendo lo siguiente.

Vuestras mercedes están en próximos de sufrir los padecimientos que sufriera Túpac Amaru, Julián Apaza Túpac Katari y muchos que no comprendieron al llamado de mi mandato y autoridad, y si llenos de un arrepentimiento a sus enormes delitos que cometieron serian puesto en la seguridad Real con todas las protecciones que se merecen (Mamani, 1982).

En un primer momento Diego Cristóbal, por desconfianza niega el indulto. Aquí, es donde tiene una intervención muy convincente del Obispo del Cuzco Juan Manuel Moscoso y peralta. El jefe rebelde acepta firma el tratado, poniendo por su lado una condición”. Diego Cristóbal Túpac Amaru remite una carta aceptando firmar un tratado. Allí expresa el temor de la muerte no me hace trepidar en nada.

La carta que le fue entregada a Diego Cristóbal, el Obispo del Cuzco, que era un español peruano y que había trabajado incesantemente para restablecer la calma, entablo conversaciones con el mencionado Diego, que consistió finalmente a deponer las armas, a condición de que se le acordará solamente el perdón a nombre del Rey y con los honores y sueldo de un coronel. Pero aparentemente por poco tiempo. 
Además, los españoles perfectamente conocían el espíritu compasivo de Diego Cristóbal, quien se hallaba siempre, dispuesto a otorgar el perdón, clemencia de quienes solicitaban, de esta manera fue presa fácil al convencimiento y debilidad de su corazón y de sus nervios, Diego Cristóbal se acogió a la amnistía el 10 de diciembre en la ciudad de lampa donde intercambia las negociaciones con el jefe realista el 11 de diciembre de 1781 y firmado el documento con el Comandante Ramón Arias como representante del virreinato del Perú, este acto solemne asistieron muchos curas, cámaras del obispo del Cuzco, militares de la plana mayor y capitanes de la columna de Arequipa, soldados de ambos bando.

Desde entonces se confirma que este acontecimiento, es considerado como una traición de parte de Diego bien planeada por los españoles con el fin de dividir a los revolucionarios Vilcapacinos y tupacamaristas. Cabe indicar que el tratado se realizó con la finalidad de dividir a los patriotas para así poder derrotar fácilmente a Vilcapaza.

Por otro lado, el tratado de lampa tal como indica. Turpo y Melchor (1971) fue firmada sin conocer otros jefes luchadores. "Cuando el Mariscal del valle exige rendición a los indios peruanos que acaudilla Pedro Vilcapaza, esta contesta que antes quería morir que ser indultado" (p. 74).

La decisión de poner fin a la guerra marca una división profunda entre los rebeldes. Unos obedecen y otros se niegan. Unos representan la organización y la confianza en el mando, los otros son la expresión de la profundidad del movimiento, de los que se refugian en la 'posiciones más radicales y primitivas, en donde el valor heroico no puede suplir la impotencia que ha debido reconocer el caudillo (Durand, 1973). Pedro Vilcapaza se niega a aceptar el indulto y muere gritando: ipor este sol que nos alumbra aprended como yo!

Diego Cristóbal, luego de juramentar su fidelidad al rey se retiró para el Cuzco abandonando la causa revolucionaria, con este hecho debió terminar la revolución. Pero aún no. Había un hombre superior, capaz de sostener el alto los pendones revolucionarios de la libertad. El General Vilcapaza se sumergió a la tarea de reclutar y de reorganizar gentes, para formar ejércitos, controlar a la provincias ganadas o adictas a la causa. Fueron meses de incansable actividad. Vilcapaza ahora era un nuevo Che Guevara de su época. Su lema era "vencer o morir" decía Pedro Vilcapaza.

"No puedo entregarme atado de pies y manos a nuestros enemigos y morir cubierto de ignominia, el pueblo me reclama y debo estar con él.” Decía Vilcapaza a ese pueblo, y se fue a sus cumbres a convocar a sus coroneles y sus huestes con el alarido de su pututo. Para jurar ante los apus tutelares la lucha a muerte. La frase dicha por Vilcapaza y que resume su recia personalidad: "Es más honroso morir en el combate que entregarnos a un enemigo que tanto nos ha oprimido". La propuesta por los españoles no era sincera ni honesta, y se utiliza solamente como un medio para exterminar a los caudillos. 
Una vez que los rebeldes tupacamaristas firmaron la capitulación, aceptando el indulto, Pedro Vilcapaza y su grupo de capitanes se negaron a rendirse, Vilcapaza se convirtió en líder de la resistencia donde prosiguió con la lucha revolucionaria, dirigiendo la sublevación con el cargo de "Comandante General". Pedro Vilcapaza tenaz en sus propósitos y en la desconfianza hacia los españoles, rehusó toda invitación, rechazo toda propuesta y no tembló ante las más duras amenazas permaneció en armas, reuniendo a todos aquellos que seguían combatir por la causa india y contra la ferocidad de los dominadores.

\section{Pedro Vilcapaza en sus tiempos finales de su lucha por la libertad}

Habiendo desertado varios Vilcapacinos, los indios mostraron una moral baja, sin resistencia a continuar en las luchas, por la escasez de los alimentos, por los sufrimientos incontables que tuvieron físicamente y moralmente, por todos estos hechos disminuyo el valor combativo del ejército revolucionario. Pedro Vilcapaza retomaría su plan propuesto a Diego Cristóbal, para retirarse a Sandia o San Gabán para recobrar fuerzas. Vega (1981) señala: Pedro Vilcapaza proyectaba descender en la ceja de selva. A la de San Gabán o la de Sandía, para resistir desde allí a las tropas del virrey; esto era el proyecto este era el proyecto que planteara a Diego Cristóbal en noviembre del año anterior y que deprimido el inca no quiso asumir. (p.36). El 31 de marzo de 1782, del Valle, emprende su paso desde Sicuani hacia Azángaro para dirigir operaciones militares realistas, que hasta entonces Vilcapaza no había sido capturado aún.

El 2 de abril de 1782. El ejército realista recibe más combatientes para enfrentar a Vilcapaza de las zonas de Huancané, Vilquechico, y Azángaro. (Seraylán, 1984) Más adelante el 5 de abril, luego de recibir refuerzos de Huancané Vilquechico y Azángaro, Piélago decide marchar a Putina para buscar a Pedro Vilcapaza. Estaciono en Rosaspata y recibió un refuerzo de 250 hombres con 30 bocas de fuego y mil cartuchos de Lampa. El día 6 Piélago se reunió Orellana que llego con 150 hombres armados de lanzas y palos y 30 bocas de fuego. 300 auxiliares honderos, balas de calibre, metralleta y 200 cartuchos. Los realistas salieron con dirección a Putina porque Fernando del Piélago, había averiguado únicamente Vilcapaza iba con dirección a Putina, razón que por la cual acamparon en rosaspata, donde el 6 de abril se enrumbaron con dirección a hacia Putina.

\section{La última batalla de Pedro Vilcapaza Kimsa Sullka}

Pedro Vilcapaza se encontraba en momentos difíciles, porque Diego Cristóbal Túpac Amaru lo había abandonado y traicionado al acogerse en la amnistía del indulto lo cual había disminuido la moral de las masas indígenas y de los demás caudillos, pero esto no fue un impedimento para el caudillo Pedro Vilcapaza, tenía una gran responsabilidad que cumplir frente a la promesa que hiciera a la masa indígena y que nunca podría traicionar a la masa indígena y en especial a los que verdaderamente lo apoyaron en cada momento de sus lucha.

Cuando Vilcapaza, estaba en Nequeneque, recibe un aviso del avance de los realistas, pues sobre esta advertencia Vilcapaza comprendió que el jefe realista venía con el propósito de hacerle una cacería decisiva, con aquella acción pensó que sería la definitiva. El domingo 7 de 
abril de 1782. Esta es la fecha y la batalla culminante de la fuerza rebelde de "Sallqa" o "Puma Indomable”. El mariscal José del Valle, buscaba a Pedro Vilcapaza con la codicia del cazador, a una presa muy preciada y que, en aquellos momentos, era invalorable. Las fuerzas realistas se van decididos a enfrentarse con el valiente General indio Vilcapaza, acuerdan acorralado y cogerlo en su propia madriguera en Muñani.

Los realistas al mando del Piélago- que ha asumido la jefatura de la operación, por enfermedad de José del Valle que ha quedado en Azángaro - van cerrando el cerco hasta acorralarlo en las alturas de Muñani. En tanto que el General Pedro Vilcapaza a pesar de su inferioridad, como último heredero de José Gabriel Túpac Amaru, como jefe máximo de la Revolución tenía una responsabilidad que cumplir frente a la promesa que hiciera a toda la masa indígena y que nunca podía traicionarlo a los que verdaderamente ayudaron en todo momento, en este entender como las gotas de las lluvias que sirve para que germine las semilla, estaría dejando sus últimas gotas de sudor y sangre en el batalla y sirviera como semilla que algún día brotaría y maduraría con el correr del tiempo.

Se acercaba los refuerzos indígenas de Vilcapaza, venidos desde, Putina, Chupa, Huacho, Samán, y algunos valerosos de Huancané con el fin de formar un ejército fuerte y poderoso, pero fueron detenidos en las alturas de Tiklla Qocha o Qoito Qollo, por las fuerzas del ejército de Fernando de Piélago, trasladándose a la región de Moro Orqo y Muñani; en tanto que el Caudillo Vilcapaza se encontraba en las alturas del distrito del Muñani; entre los desfiladeros de "Lloqha" y "Nekeneke" que son lugares de caminos hacia Sandia, en la cadena de la cordillera o altura de Kinsa Sullk'a. Se sabe que Pedro Vilcapaza fue presionado por sus coroneles y fieles colaboradores que tomara su destino de huir a las selvas de Sandia o San Gabán y desde allí dirigir la lucha, después de un tiempo que pasara las amenazas y las sangrientas ejecuciones. Los ruegos y suplicas eran vanos (Pompeo, 1977, p. 29-30).

Tal como intuyo Vilcapaza, los planes de los realistas se realizaron con inexorable precisión. Donde el jefe español organizo una gran estrategia que resultó ser una gran estrategia de casería. Por qué el ya conocía la astucia de su enemigo. Donde la caballería del Piélago y del Valle se desplazaron y bloquearon los caminos de los reveles.

La caballería del Valle cruza por el Norte y ataca sorpresivamente por la quebrada de Paikka (Paiqa) sembrando el desconcierto, los indios se repliegan hacia la cumbre batiéndose como fieras acorraladas, el combate es desigual piedras contra balas (Luna, 1982). El choque es horroroso el grupo queda convertido con una papilla sangrienta y deforme su efecto es igual al de una bomba de gran potencia que explota sobre un grupo. Miembros seccionado cabezas aplastadas, armas sanguinolentas saltaron al aire en una zarabanda macabra. Pedro Vilcapaza cae traicionado por los dominicos de Santiago de pupuja, putina y por su sobrino Julián Vilcapaza se presume que el guio a los realistas para su captura de caudillo.

\section{La captura de Pedro Vilcapaza}


El incremento y poderío del ejército Realista logra cercar y derrotar a Vilcapaza en la batalla del cerro Kinsa Sulk'a, en Nequeneque. Pedro Vilcapaza, al verse perdido, no quiso huir con un grupo de leales de sus huestes que le instaba y le rogaba. Que trato de encaramarse en una galga gigante que, con titanio esfuerzo que acaban de remover de su granítico lecho, en un bólido humano, caer sobre el enemigo. En un postrer esfuerzo desesperado quería pulverizar a sus enemigos. Pero la fatalidad lo salvo. Frustro su intento suicida. La galga no le dio tiempo. Salió disparada. A los pocos instantes como chacales hambrientos, cayeron sobre los soldados realistas que habían avanzado por el lado opuesto del cerro Sullk'a, expresamente mandados por el jefe español para captúralo vivo o muerto.

Aquel cerro, pukara de la resistencia varonil del indio, quedo como un monumento que la naturaleza hubiese erigido para inmortalizar aquella sangrienta acción de armas. Estos restos hablan con mucha elocuencia de aquella épica acción. Allí cayó al fin como un valiente aquel guerrero indomable.

Según Mamani (1982), los artífices de la captura fueron tres ejércitos realistas. "Fue atacado por el ejército dirigido por el Coronel Fernando de Piélago venidos desde Arequipa y Moquegua, más el ejército del valle y del cura de Vilquechico" (p. 87). Por órdenes del Mariscal José del Valle, fue conducido desde Muñani hasta Azángaro con una escolta de (300) jinetes a Pedro Vilcapaza; que se le abrió proceso y luego fue ajusticiado con el descuartizamiento por ocho caballos. Finalmente, de acuerdo a. Seraylán (1984), confirma que Pedro Vilcapaza fue entregado en Azángaro al Mariscal José del Valle como prisionero. "El 7 de abril de 1782, llego a Azángaro, donde fue entregado prisionero el coronel, general, caudillo Pedro Vilcapaza" (p. 969).

Una vez caído prisionero, fue sometido a tortura durante toda la noche, por haber atentado contra la Corona España. Ante estos tormentos respondía a sus torturadores con escupitajos e ironía. Una vez tomado preso Vilcapaza fue llevado a la casa del Cacique Tomas Mango Turpo, luego el caudillo es interrogado y torturado en la iglesia de Azángaro, donde sus captores le ofrecieron la libertad si declaraba donde se encontraban los tesoros que logro incautar durante toda su batalla, donde Vilcapaza respondió irónicamente. Luna (1982) diciendo la siguiente frase. "Vuestra cobardía me da asco. Sé que si no declaró me van a matar, pero si declaro voy correr la misma suerte. No hablare. Miserables y Cobardes imátenme de una vez!” (p. 85).

Una vez que Vilcapaza fue tomado preso, lo primero que lo interrogaron los realistas sedientos de las riquezas, es sobre el paradero del tesoro que habían recolectado durante sus batallas, donde su sobrino Toribio Vilcapaza entrego 21 cofres de oro y de plata tal vez, considerando este tesoro como prenda de rescate de su tío, lo cual era imposible. Estas riquezas que entro su sobrino habrían sido suficiente para reorganizar la resistencia en sandia. Del Valle en Azángaro, donde reunió un consejo de guerra para dar la sentencia a muerte al general Pedro Vilcapaza, traicionado por uno de los suyos, en Azángaro el Mariscal del Valle, Fernando del Piélago, el obispo de Moscoso, Diego Choquehuanca, Mango Turpo y 
el traidor de la rebelión indígena Diego Cristóbal en un consejo de Guerra sentencia a Vilcapaza.

\section{Acusaciones a Pedro Vilcapaza}

El Caudillo Pedro Vilcapaza Alarcón es acusado, por el Mariscal José del Valle Torre, por los siguientes quebrantamientos cometidos:

- Por haberse levantado en armas contra su señor Rey su amo.

- Por haber creado disturbios en contra de la tranquilidad del orden público.

- Por enfrentarse contra el ejército Virreinal y traición al Virrey.

- Por haber organizado un ejército revolucionario en contra de la seguridad de los españoles.

- Por organizar las diferentes guerrillas.

- Por proclamarse como Caudillo del Ejército Revolucionario sin conocimiento de causa sobre la organización a espaldas de sus hermanos de lucha.

- Por haber obligado a los indios a viva fuerza para integrar en la organización del ejército.

- Por engañar a los indios falsamente y haciendo creer sobre la mala administración y abuso de autoridad en el virreinato.

- Por las pérdidas cuantiosas en el ingreso económico en el virreinato para su sostenimiento.

- Por la paralización de todos los centros mineros en la explotación.

- Por las paralizaciones de trabajo en el campo agrario

- Por la paralización del comercio y las industria en todos los virreinatos.

- Por propiciar en levantamiento de los indios en contra de las autoridades del virreinato.

- Por incautar los tesoros incalculables de los españoles y de los caciques fieles al rey su señor y los tesoros millonarios de los caciques de Diego Choquehuanca, Mango Turpo y Calsina.

- Por los incedios a los pueblos de Huancané, Vilquechico, Sorata y otras comarcas del Collao y Alto Perú.

- Por los exterminios horripilantes de los pueblos Paucar Qolla, Santigo de Pupuja donde la sangre clama al Rey.

- Por la muerte de miles de españoles y curas.

- Por la muerte de miles de indios.

- Por incumplimiento de pagos por los tributos que eran una obligación y raíz de los levantamientos dejaron de pagar.

- Por la desobediencia de los indios a las autoridades virreinales.

- Por las pérdidas de miles de vidas inocentes en las batallas de Condorcuyo, Qan Qhari, Kinsa Sulk'a, Mamanchilli en Juliaca, Inampu y otros.

- Por el sitio a la ciudad de Puno.

- Por el triste viaje de Puno a Cusco, donde padecieron y la perdida de muchas vidas.

- Por acumulación de cuantiosos tesoros que fueron ocultados para continuar luchando.

- Por la acumulación de todos los tesoros a su favor.

\section{Holocausto de Pedro Vilcapaza}

Aquel 8 de abril de 1782 en la provincia de Azángaro, el caudillo Pedro Vilcapaza tomado como prisionero, fue torturado por los españoles durante toda la noche por haberse sublevado 
en contra de la corona española. A Vilcapaza le ofrecieron el perdón y comodidades, donde no lograron convencer ni intimidar. El mismo José del Valle le ofreció el perdón y poder todo a cambio del tesoro escondido, pero no pudo sacarlo ninguna respuesta mientras se procedían los interrogatorios y los preparativos para el juzgamiento de Vilcapaza. Habían iniciado una reunión de consejo de Guerra en la casa de Diego Choquehuanca donde estaban reunidos del Valle, Piélago, Moscoso, Mango Turpo, Curas de Santiago de Pupuja, Lampa y los algunos generales de Azángaro.

\section{El macabro Juicio y descuartizamiento del caudillo Pedro Vilcapaza}

Aquel macabro día del 8 de Abril de 1782 donde Vilcapaza fue condenado a muerte en la plaza de Azángaro, fueron escenas aterrorizantes y horrorizantes para los patriotas. Donde otros sollozaban por el caudillo Pedro Vilcapaza, mientras que los realistas daban vivas a su Rey. Después de haber cercado el cuadrilátero con milicias sedientos de sangre, en todas las entradas de las calles de la plaza estaban colgados cuerpos como racimos de plátanos que fueron familiares, jefes y seguidores del caudillo, ahorcados con toda anticipación creando arcos humanos por donde iban caminando los patriotas traídos para presenciar la macabra muerte del caudillo Pedro Vilcapaza, ahorcamientos de los centenares de rebeldes.

En el cuadrilátero de la puerta de la iglesia donde fue preparado con anticipación el tabladillo especial para los realistas, donde todos los realistas estuvieron vestidos de gala donde estuvieron presentes José del Valle, Fernando de Piélago, el traidor Diego Choquehuanca, caciques leales a la causa realistas y en especial Diego Cristóbal el traidor de la causa revolucionaria, traído especialmente para presenciar la macabra muerte del Puma Indomable.

Donde finalmente se da la lectura de la sentencia al lado de una picota, lectura a cargo de un secretario del auditor de guerra. Oíd huestes e indiada de Omasuyos: el consejo de guerra a vos de nuestra majestad Carlos III, príncipe del palacio Borbónico y Rey de España. Por la santa iglesia católica apostólica romana por la Paz del Virreinato de España condenó a muerte al cabecilla insurrecto Pedro Vilcapaza y sus cómplices serán ahorcados, por incurrir en traición irreparable a la Corona Española y haber atentado contra la paz del reino levantando armas y rebeldía, por haber asesinado a muchos españoles y curas, por tomar tesoros de las minas de oro y plata que pertenecen a España, por haber rechazado el armisticio firmado en Sicuani. Por todo esto Vilcapaza presenciaría la muerte de su maldita familia y seguidores, finalmente será descuartizado por caballos y destruido sus miembros en las principales salidas de este pueblo de indios llamado Azángaro, su cabeza se clavara en una picota de la plaza, como ejemplar acto de escarmiento para que esta maldita raza de indios jamás se levanten contra el reino de España y sus órdenes. Ejecución a cargo del ejército español así mismo la confiscación a las propiedades de los insurgentes (Mamani B. , 2016).

Después de la lectura de sentencia, se da inicio con la ejecución de sus lugartenientes, familiares, coroneles fieles a la causa de la revolución. Mediante ahorcamientos, con la presencia del José del Valle, donde en una parte de la iglesia se enterraron vivos a más 60

Revista Revoluciones -48- Vol. 3, No 4 (2021), pp. 26-55

Esta obra está bajo una licencia internacional Creative Commons Atribución 4.0. 
guerrilleros de Vilcapaza, hasta el cuello, para luego pasar sobre sus cabezas la caballería realista triturando las cabezas pasando tantas veces a galopes sobre ellas. Por el solo hecho de reclamar justicia este hecho que refleja aquel inhumano y cavernario acto por los españoles. Llego la hora más cruel para el caudillo Pedro Vilcapaza, el puma Indomable, varios capitanes montados en caballos le sacan del pie del tabladillo que estuvo presenciando todos los actos del dolor y martirio, arrastran hasta el centro de la plaza, cargando de cadenas y grilletas en sus extremidades cubierto con sangre masacrado el cuerpo con las horribles torturas que noche anterior le cometieron para que confesara sobre los tesoros requisados durante su campaña revolucionaria.

Tiende la mirada fulmínate como rayo al tabladillo oficial y reconoce al caudillo traidor Diego Cristóbal Túpac Amaru, al sanguinario Mariscal José del Valle, al traidor cacique Diego Choquehuanca y tantos opresores y traidores; una ira de desprecio, se voltea dándoles la espalda como quien dice que tú no eres digno de respeto sino un porquerino despreciable. Ve a su pueblo mutilado, ofendido humillado y masacrado. Hincha su tórax, levanta sus puños dirigiéndose a la multitud que está presente, y grita a los cuatro vientos "iAswan qharis, por este sol aprended a morir como yo!" (Ramos, 1971) que en idioma quechua quiere decir: "illaqta masiykuna ñoqa hina wañuita yachaychis!"

Así llegó la hora del caudillo en la plaza, frente a la única iglesia de Azángaro, donde enfurecidos los españoles lo derribaron al suelo donde fue atado por sus cuatro extremidades en la cincha de cuatro caballos que iban a descuartizarlo a una voz de mando, luego los caballos arrancaron relinchando a cuatro direcciones opuestas. Donde no fueron suficientes solo cuatro caballos para el descuartizamiento, donde del Valle ordena doblar el número de caballos, las ocho vestías no pudieron descuartizarlo donde no se logró arrancar las extremidades. Luego la comitiva ordeno el degollamiento a cuchillo, lo cual fue cumplido en el acto.

Donde la muchedumbre horrorizada del holocausto, estremecieron de lágrimas y dolores de consternación para una nueva venganza. La cabeza de Vilcapaza fue izada en un poste en la plaza al frente de la iglesia, que aun muerto Vilcapaza tenía una mirada brillante y fulminante que con tal sola mirada seguía ordenando a su gente. Mientras tanto las extremidades mutiladas fueron destinadas a diferentes direcciones y a principales caminos de la provincia de Azángaro. Que según los españoles viendo esta horrible carnicería, los patriotas no volvieran a sublevarse contra la corona española.

- Una pierna fue izada en Makaya camino que se dirige a Tintiri, Moro Orqo.

- La otra en la Apacheta de K'ayrawiri, camino a Lampa.

- Un brazo en Qanqari, camino a puno.

- El otro brazo en Wilk'iKunca, camino a Asillo.

En donde el cuerpo fue arrojado a una hoguera ardiente luego convirtiéndole en cenizas para que luego estas cenizas fueran echadas a los vientos. 


\section{La cabeza del Puma indomable}

Con referente a la cabeza de Vilcapaza se tiene muchas suposiciones lo cual ocasiona mucho misterio con lo referente a la cabeza del caudillo. La cabeza del Puma no podía seguir sobre la picota del escarnio, era una vergüenza para los indios. Desde lo alto del poste, con la dura mirada de sus ojos vidriosos, parecía dirigir a los indios un amargo reproche. Parecía que iba a rugir. Diríase que hasta después de muerto el gran rebelde seguía ordenando y se hacía obedecer. Así sucedió. Una mañana no amaneció. No se sabe quién, pero alguien derribo el poste y se llevó la cabeza. Pompeo (1977) menciona:

La altanera cabeza fue colocada, en una picota, en la puerta principal de la iglesia, como trofeo macabro de los Pizarro y los Areches. En la oscuridad de la noche, del aquel infausto día, desapareció la cabeza. Parientes y parciales del mártir, la robaron para enterrarlo no se sabe dónde (p. 32).

Se ratifica que la cabeza de Vilcapaza haya sido hurtado por sus parientes y paisanos de Moro Orco y llevado a su caserío de Raya Pata, como se indica: la cabeza de Vilcapaza fue puesta en una picota frente a la iglesia, de donde desapareció misteriosamente fue robada por los moradores de Mororco quienes lo llevaron a su caserío de Raya Pata donde fue velado por tres días y tres noches y que después fue enterrado cerca de la laguna de Putislaka, como fiel guardián del tesoro que había escondido y que es uno de los motivos en que no se puede encontrar dicho tesoro.

De acuerdo al estudio de la vida de Vilcapaza se sabe que, Antonia fue hermana del caudillo, según la historia contada se presume que la hermana de Vilcapaza presencio el horrendo holocausto de su hermano, viendo todo el horror que hicieron los españoles Antonia perdió la Razón. Ramos (1982) donde menciona:

La mujer de nombre Antonia Vilcapaza, perdió la razón y diariamente en los caminos recogía los huesecillos blanquecinos que se hallan desparramados, para llevarlos los domingos al templo de Azángaro con la idea de que esos huesos correspondían a su hermano, primo o sobrino (p. 333).

Antonia Vilcapasa estuvo por varios días cargando la cabeza de su hermano sin quererlo soltarlo, pero sus familiares lograron despojarlo para enterrarlo. Después Antonia seguía caminando por los caminos de Moror Orko hacia Muñani, otras veces por el camino hacia Azángaro, andaba por los cerros, por los cementerios, luego no se sabe más de ella.

En la iglesia de Azángaro se sepultó la cabeza de Vilcapaza después de que fue ajusticiado, como los españoles acostumbraban descuartizar los cadáveres para exhibirlos, la cabeza de Vilcapaza, una vez mostrado en una picota de poste se recuperó, para luego sepultarlo refiere Basadre en su libro tantas veces citado, dice que los patriotas robaron la cabeza de Vilcapaza y lo enterraron y que años más tarde al estar buscando tesoros en la iglesia encontraron, un gran tesoro debajo de un confesionario en la iglesia. Tal como señala Romero, (2013) "hechas

Revista Revoluciones $\mathbf{- 5 0 -}$ - Vol. 3, No 4 (2021), pp. 26-55 
la indagaciones se extrajo una caja o cofre valioso y al descubrirlo, se vio que tenía la cabeza de Vilcapaza enterrada hay por sus amigos." (p. 333)

\section{Versiones sesgadas sobre la cabeza de Vilcapaza}

Otra versión nos presenta Luis Gallegos (2006) aunque no tan coincidente por el tiempo, puesto que el templo de Tintiri se construye en el año 1869, hasta esa fecha no podía estar viva Manuela (...) cada año en la romería de la fiesta del Señor de la justicia del 14 de setiembre en el templo de Tintiri asistía una anciana descansando en las doce estaciones con un atado de hiervas medicinales para vender a los peregrinos en la fiesta. Sentada en la puerta del templo ofrecía su mercadería. El coronel José María lizares Quiñones curioso se acercó donde la viejita y dando una pata en el atado de hiervas medicinales dijo; "que vende esta vieja”. Y descubre que dentro de las hierbas había una calavera que con la patada empezó a rodar. Después se supo que la anciana era Manuela Copacondori Choquehuanca (...). La referida calavera de inmediato fue enviada a enterrar en los sótanos del Templo de Tintiri.

Con respecto a la versión anterior hay una contradicción, puesto que Rafael Apaza (2016) Afirma lo siguiente: la cabeza de Pedro Vilcapaza, uno de los lugartenientes de Túpac Amaru II. Se enterró en el templo de Tintiri.

\section{DISCUSIÓN}

A partir de los datos encontrados en la investigación, la población azangarina, después de muchos años de explotación y dominación he aquí su gran significado. Las sublevaciones del caudillo Pedro Vilcapaza, fue la rebelión social más grande de la historia en el Altiplano puneño surge como resultado de la situación dominante, esta rebelión social, fue portador de objetivos de libertad y justicia de la nación étnica Quechua-Aimara; la abolición de la tiranía de los encomenderos, corregidores y caciques. Las sublevaciones de Vilcapaza nos permiten observar el gran contenido social, que son acciones colectivas encaminadas a resistir o promover un cambio en la sociedad o grupo social del cual forma parte. Pedro Vilcapaza, lucha por un pueblo explotado; donde se opone a los tributos. Fue esta una de las causas principales que motivo al pueblo Quechua-Aimara, encaminar el cambio social con el fin tener la libertad e independencia, aboliendo el régimen colonial.

Diego Cristóbal, luego de juramentar su fidelidad al rey se retiró para el Cuzco abandonando la causa revolucionaria, con este hecho debió terminar la revolución. Pero aún no. Había un hombre superior, capaz de sostener el alto los pendones revolucionarios de la libertad. El General Vilcapaza y sus patriotas prosiguieron con la guerra hasta la muerte, fue el segundo umbral. En 1781 donde combatieron en, Cundurcuyo-San José, Llacchata, PuquinacancariAzángaro y Kimsa Sullka. Touraine (1995) sostiene, que un movimiento de liberación nacionalista, puede cambiar la política colonial. España presionado, abolió en 1781, la arbitrariedad del corregimiento utilitarista, tirano y corrupto. En Abril de 1782, el Coronel Pedro Vilcapaza con su ejército en donde la gran parte mortífera del hambre, el agotamiento, 
las enfermedades y el clima severo, limitaron la intensidad de la lucha, para poder derrotar el régimen colonial.

La inferioridad del movimiento social, Pedro Vilcapaza en sus momentos finales, la terminación de la guerra, fue desastrosa el 7 de abril de 1782. El caudillo Pedro Vilcapaza combatió en su última batalla en las alturas de Kinsa Sullka”- Muñani, donde los rebeldes apenas contaban con escasos armas de fuego, palos, ondas, piedras y hubo deserciones y traiciones, en donde el ejército patriota se desorganiza, Pedro Vilcapaza, al verse perdido, no quiso huir con un grupo de leales de sus huestes que le instaba y le rogaba. Pero la fatalidad lo salvo. Frustro su intento suicida. La galga no le dio tiempo. Salió disparada. A los pocos instantes como chacales hambrientos, cayeron sobre los soldados realistas, expresamente mandados por el jefe español para captúralo vivo o muerto. Fue entregado a su perseguidor Mariscal de Campo José del Valle (Español), traído a Azángaro, casona de su rival, cacique Tomas Mango Turpo. Fue sometido a tortura confesión inquisitoria y perversa, en el templo colonial “N.S. Asunción”. El Coronel Pedro Vilcapaza, hizo valer su identidad y principios de oposición: donde menciona la siguiente frase "No quiero ser vasallo de tiranos, solo quiero la libertad o la muerte". No suplicó perdón, resistió torturas, lo sacaron del templo colonial masacrado. Tiende la mirada fulmínate como rayo al tabladillo oficial y reconoce al caudillo traidor Diego Cristóbal Túpac Amaru, la sanguinario Mariscal José del Valle, al traidor cacique Diego Choquehuanca y tantos opresores y traidores; una ira de desprecio, levan sus puños dirigiéndose a la multitud que está presente, y grita a los cuatro vientos "iAswan qharis, por este sol aprended a morir como yo!" que en el idioma quechua quiere decir: "illaqta masiykuna ñoqa hina wañuita yachaychis!".

El movimiento social, protagonizó la libertad, contraria a la dominación colonial extranjera y la estructura de opresión; clarificó la conciencia de igualdad natural, la oposición a la tiranía y mentalidad de rapiña de España. El Caudillo Pedro Vilcapaza, murió asesinado el 8 de abril de 1782, cuatro caballos arremetieron, tirando sus extremidades. No lograron arrancarlos, doblaron a 8 caballos, fracasó. La suma de la violencia física, fue la carnecería con apunalamiento, corte a hachazos sus extremidades y cabeza; tras ello, quemado su cuerpo. La plaza frontis, casona feudal Choquehuanca, fue la tumba libertaria del Coronel en jefe del movimiento social emancipador. Ejecutado por el genocida verdugo Coronel Fernando del Piélago, criollo arequipeño a quién lo combatió en "Huaychu" y "Moho", por orden del Mariscal José del Valle y Joaquín Orellana (españoles). Stompka (2004), sostiene en la terminación del movimiento social, hay dos posibilidades: optimista, el movimiento vence y por tanto, pierde su rasión, desmovilizándose y disolviéndose; la otra es pesimista, el movimiento no vence sino que es suprimido y derrotado o, agota su potencial de entusiasmo y decae sin conseguir la victoria. Al ser derrotado el ejército "patriota" a falta de logística bélico moderno, agotó su potencial de entusiasmo de sus componentes y decayó, al no conseguir la victoria final.

Para finalizar es relevante señalar que dentro de las sublevaciones del altiplano puneño encontramos aspectos comunes puesto que la gran parte de las rebeliones resultan fallidas,

Revista Revoluciones -52- Vol. 3, No 4 (2021), pp. 26-55 
donde el objetivo que se proponen los revolucionarios en la mayor parte no se logran el objetivo propuesto, ni por las masacres que sufrieron los patriotas o campesinos no pudieron ser recuperados las tierras, por el contrario, los indios han sido exterminados y perseguidos.

\section{CONCLUSIONES}

Pedro Vilcapaza durante la sublevación de los años 1780-1782 actuó con mucha celeridad en defensa de la clase social, Vilcapaza se inclinó a la sublevación esencialmente por el problema de la tierra, su defensa y rescate de ella, el objetivo de lucha, era abolir las estructuras de sobreexplotación corporal esclavo y la servidumbre feudal, la mita, obrajes, haciendas, repartos y tributos. Estas fueron evidenciadas para los arrieros tupacamaricas y para el caudillo Pedro Vilcapaza, causando en ellos una conmoción social, esta fue una de las causas principales a la gran rebelión histórica del pueblo, para poder sublevar y expulsar de tierras andinas a los dominantes españoles.

Las batallas comandadas por el caudillo Pedro Vilcapaza Alarcón, el ejército Patriota, se batió heroicamente contra el ejército Realista, en la batalla de Condorcuyo, en el enfrentamiento en Llacchata, la batalla de Puquina Qanqari y la batalla de Kimsa Sullka, fue uno de los sucesos históricos de valiosa importancia para conseguir la independencia y deshacernos de la cruel dominación española, que dominó y esclavizo al pueblo andino de Azángaro por varios siglos de pánico. Por la que surgió la necesidad de la emancipación, siendo esta situación de esclavitud la principal causa que encendió el levantamiento de los rebeldes, en las cuales los patriotas lucharon por conseguir la libertad, hombres valientes que lucharon y muchos de ellos dieron la vida, y sobre todo por ver un país libre y soberano en el futuro.

La sublevación de los patriotas ocasionó muchas consecuencias tales como sociales, militares y políticas, dejando en desorden al país, hubo muchas pérdidas de vidas humanas y también daños materiales. Conocer la historia es muy importante, y más aun de las batallas que acaudillo Vilcapaza ya que estalló en el territorio puneño el cual marco un hito muy importante en la historia en el Altiplano, lo cual debe ser una cuestión de identidad, ya que cada pueblo mantiene su historia, tradición oral, costumbres, vestigios o monumentos y los pasajes más brillantes de su historia.

\section{REFERENCIAS BIBLIOGRÁFICAS}

Aragón, P. (1977). General Vilcapaza. Puno: Los Andes.

Calsín, R. (2005). Historia de Azángaro (Primera ed.). Arequipa: IPEJAE.

Canahuiri, F. (1994). Rebeliones Indígenas en el Perú y Azángaro. Lima: Rusinka.

Canaza-Choque, F. A. (2019). Pluri-versalismo transmoderno decolonial en la crisis civilizatoria: una lectura clave a Grosfoguel. Cátedra Villarreal, 7(1), 29-34.

Canaza-Choque, F. A. (2020a). Educación superior en la cuarentena global: disrupciones y transiciones. Revista Digital de Investigación en Docencia Universitaria, 14(2), 1-10.

Canaza-Choque, F. A. (2020b). La gran estampida. Humanos caminando en la modernidad líquida. Encuentros. Revista de Ciencias Humanas, Teoría Social y Pensamiento Crítico, (12), 127-145.

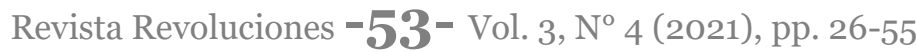

Esta obra está bajo una licencia internacional Creative Commons Atribución 4.0. 
Canaza-Choque, F. A. (2020c). Mariátegui y la agonía de los dioses. Entre encuentros, presagios y desgracias futuras en el panteón andino. Acta Herediana, 63(2), 135-151.

Canaza-Choque, F. A. (2020d). Desafiar y desactivar el mal. Percepciones y notas sobre un desastre climático global en estudiantes de Educación Secundaria. In Crescendo, 11(3), 221-247.

Canaza-Choque, F. A. (2021a). «Por nuestras muertas». El despertar de un poder y la movilización de Ni Una Menos [NUM] en el Perú de 2016. PURIQ, 3(1), 22-47.

Canaza-Choque, F. A. (2021b). El Perú de Mariátegui: detenidos en el tiempo y el despertar de una era. Horizonte de la Ciencia, 11(20), 45-57.

Canaza-Choque, F. A. (2021c). Pandemia 2020 y el poder del Estado. Daños, impactos y respuestas a zonas desprotegidas en escenarios devastadores. Socialium, 5(1), 56-74.

Canaza-Choque, F. A., Supo, F., Ruelas, D., \& Yabar, P. S. (2020). El regreso del Puma Indomable. Neoliberalismo y las luchas sociales desde la escuela pública en el sur del Perú. Revista Conrado, 16(74), 154-161.

Canaza-Choque, F. A., Cornejo-Valdivia, G., Condori-Pilco, L. B., \& Yabar-Miranda, P. S. (2021). Trayectorias y desafíos. El reto de ambientalizar e institucionalizar el cambio climático en la Educación Superior Universitaria. Paideia XXI, 11(1).

Carrasco, S. (2006). Metodología de Investigación Cinetífica. Lima: San Marcos.

Charaja, F. (2018). El Mapic en la Investigación Científica. Puno: Corporación SIRIO EIRL.

Condori, R. (2015). Historia de Pedro Vilcapaza. Puno-Perú: UNAP.

Cuevas, R. (1984). Pedro Vilcapaza la Rebelión en el Altiplano Peruano 1780-1782. Puno: Andina.

Durand, L. (1973). La Independecia e Integración en el plan Político de Túpac Amaru. Lima: PLV.

Durand, L. (1981). La Revolución de los Túpac Amaru. Lima: Antología.

Espezúa, R. (2006). Pesquisas de 51 Puneños Ilustres (1ra ed.). Puno: Naupas.

Frisancho, I. (1980). El Altiplano Puneño de Túpac Amaru y Pumacahua. Puno-Perú: Samuel Frisancho Pineda.

Frisancho, S. (1968). Monografía de Puno (Vol. Tomo I). Puno: Álbum de Oro.

Huanca-Arohuanca, J. W. (2019). El despertar de una nueva era: colonización y camino hacia la revolución. Revista Revoluciones, $\quad 1(1), \quad 1-3$ http://revistarevoluciones.com/index.php/rr/article/view/1/2

Huanca-Arohuanca, J. W. (2020a). Caleidoscopio social al Covid-19: pánico y desesperación en tiempos de aislamiento. Revista Universidad y Sociedad, 12(6), 226-231. https://rus.ucf.edu.cu/index.php/rus/article/view/1836

Huanca-Arohuanca, J. W. (2020b). Contrahegemonía y la lucha por la educación en el sur del Perú. Editorial Académica Española.

Huanca-Arohuanca, J. W. (2020c). Cuando la muerte nos mira con deseo de llevarnos al tártaro. Revista Revoluciones, 2(2), 1-5. https://doi.org/10.35622/j.rr.2020.02.001

Huanca-Arohuanca, J. W. (2020d). Retropías y distopías de la educación en Puno. Revista Helios, 4(1), 270-271. https://doi.org/10.22497/Helios.41.4116

Huanca-Arohuanca, J. W. (2021). Narrativas de guerra y resistencia: participación de la mujer austral del Perú en la Guerra del Pacífico. Encuentros. Revista de Ciencias Humanas, Teoría Social y Pensamiento Crítico, 13, 50-59. https://doi.org/http://doi.org/10.5281/zenodo.4395218

Huanca-Arohuanca, J. W., Canaza-Choque, F. A., \& Flores, E. (2020). El dolor de los subalternos y el deseo de una revolución inconclusa: Narrativas sobre la violencia política en la Nación Aymara - Perú.Comuni@cción: Revista De Investigación En Comunicación Y Desarrollo, 11(2), 177189. https://doi.org/10.33595/2226-1478.11.2.436 
Huanca-Arohuanca, J. W., \& Geldrech, P. (2020). Planificación educativa y gestión pedagógicaestratégica-operacional en las instituciones del nivel inicial en el sur del Perú. Revista Conrado, 16(76), 369-376. https://conrado.ucf.edu.cu/index.php/conrado/article/view/1497

Huanca-Arohuanca, J. W., \& Núñez, L. (2020). Estimaciones y contrastes de la pandemia en Perú y en el contexto mundial. Educare Et Comunicare. Revista Científica de La Fcultad de Humanidades, 8(2), 10-20. https://doi.org/10.35383/educare.v8i2.440

Huanca-Arohuanca, J. W., \& Pilco, N. (2021). Acciones revolucionarias en Ámérica Latina: Puno y el Alto Perú durante el proceso de independencia (1809-1825). Chakiñan. Revista de Ciencias Sociales y Humanidades, 14. https://doi.org/10.1590/SciELOPreprints.1364

Huanca-Arohuanca, J. W., Supo-Condori, F., Sucari, R., \& Supo, L. A. (2020). El problema social de la educación virtual universitaria en tiempos de pandemia, Perú. Revista Innovaciones Educativas, 22, 115-128. https://doi.org/10.22458/ie.v22iespecial.3218

Livisi, M. (13 de Diciembre de 2017). Google. Obtenido de Google: Recuperado de https://www.google.com.pe/search?q=pedro+vilca\%C3\%A1za\&oq=pedro+\&aqs=chrome.2.69 i57j69i6oj69i59l2.14314joj7\&sourceid=chrome\&ie=UTF-8

Los Andes, D. (28 de Julio de 2014). Genealogía de los Choquehuancas. pág. 19.

Los Andes, D. (18 de Octubre de 2018). Google. Obtenido de Google: Recuperado de https://www.google.com.pe/search?biw=1366\&bih=657\&tbm=isch\&sa=1\&ei=dor7W4VFw4r nAo2susAD\&q=arrieros++del+virreinato+del+peru\&oq=arrieros ++ del+virreinato+del+peru \&gs_l=img.3...5557.oj2joj1j3j2j2j2j1...........1..gws-wiz-img..

Luna, L. (1952). Bronce Conmemorativo. Puno - Peru: Universo.

Luna, L. (1982). El puma indomable. Puno: Samuel Frisancho Pineda.

Mamani, B. (2016). Pedro Vilcapaza en la Rebelión Tupacamarita de 1780 a 1782. Juliaca-Puno: Hijos de la Lluvia.

Mamani, E. (2015). conocimiento sobre las batallas de Pedro Vilcapaza. Puno: UNAP.

Mamani, R. (1982). Remenbranzas al Caudillo General Pedro Vilcapaza. Sicuani-Cuzco: Prelatura Sicuani.

Mamani, R. (1982). Remenbranzas al Caudillo General Pedro Vilcapaza. Sicuani-Cuzco: Prelatura Sicuani.

Millares, E. (2004). Selección de Biografias. Lima: Ebisa Ediciones.

Nuñez, W. (2009). Conocimiento sobre la rebelion de Pedro Vilcapaza. Puno.

Ortiz, J. (2013). Didáctica de la historia regional. Puno: Altiplano.

Palao, J. (2005). Etnohistoria del Altiplano Puneño. Puno-Perú: Care-Ministrio de Educacion.

Palomino, D. (2011). Nuñoa en la Revolución de Túpac Amaru. Cuzco: UNSAC.

Palomino, G. (2010 ). Investigación y cuantitativa en ciencias sociales y de la educación . Puno: Universitaria.

Paredes, M. (2014). Homenaje al bicentenario del Sacrifio de Pedro Vilcapaza. Revista Makaya, $\mathrm{N}^{\circ}$ 14.

Ramos, A. (1971). La Gesta de Pedro Vilcapaza. Puno: Los Andes.

Ramos, A. (1982). Puno en la Rebelión de Túpac Amaru. Puno-Perú: Sistema OFFSET-UNTA.

Ramos, A., \& Mamani, B. (2009). Tupacamarus, Vilcapaza, Cataris, Ingaricomas. Arequipa-Perú: Graphic Center.

Ramos, G. (2014). Historia de la Provincia de Puno. Puno: Altiplano.

Reinaga, R. (1977). Tawa Inti Suyu. Chuquiapu-Bolivia: Internacional.

Romero, E. (2003). Monografía del departamento de Puno. Puno-Perú: Corporación MERU E.I.R.L. Romero, E. (2013). Monografía del Departamento de Puno (3ra ed.). Puno-Perú: Corporación MERU E.I.R.L. 
Salas, G. (1997). Azángaro Tierra Procer - Pedro Vilcapaza. Juliaca: Offset. Sampieri, R. (2014). Metodología de la investigación. México: Mexicana.

Seraylán, A. (1984). Historia General del Ejército Peruano (Vol. 3). Lima: Imprenta del Ministerio Guerra.

Sivirichi, A. (1979). La Rebelión Social de los Túpac Amaru. Lima: Editorial Universo S.A.

Talavera, J. (1983). Monografia Azángaro: Pasado y Presente. Azángaro - Puno: Zona de Educación.

Tamayo, M. (1998). Aprender a investigar. Colombia.: ICFES Editorial Cali.

Turpo, F. (1971). La Rebelión de Vilcapaza. Arequipa: Ediciones Casa de la Cultura.

Valcárcel, C. (1972). Túpac Amaru, San Martín y Bolívar. Lima: Imprenta de la Universidad Nacional Mayor de San Marcos.

Vega, J. (1981). Historia General del Ejército Peruano. Lima: Imprenta del Ministro de Guerra.

Vega, J. (2005). Vilcapaza y los Tupacamaristas Puneños. Revista de la Universidad U.T.A(3).

Voz y Sentimiento Azangaro. (2016). Revista Bimestral(35), 6. 